$$
\begin{aligned}
& \text { تدريس مادة تاريخ العمارة_ _الأهداف والوسائل } \\
& \text { قراءة في أدبيات مناهج تدريس تاريخ الأريخ العمارة } \\
& \text { ضحى عبد الغني عبد العزيز القزاز } \\
& \text { مدرس مساعد في قسم الهندسة المعمارية / جامعة الموصل الفرل }
\end{aligned}
$$

\title{
الخلاصة
}

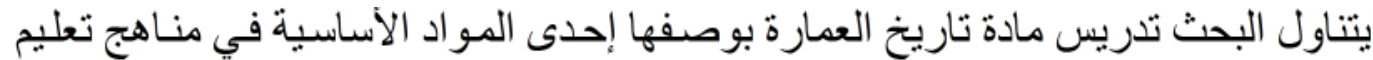

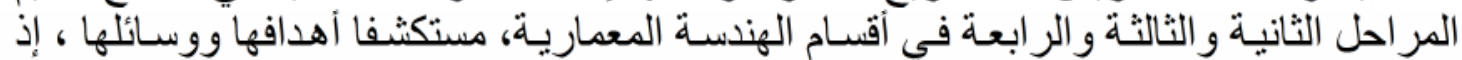
تر اوحت أهدافها بين أهداف مباشرة تتعلق بتطوير قدرات الطلبة الفكرية وتوسيع أفاقهم المعرفيـة

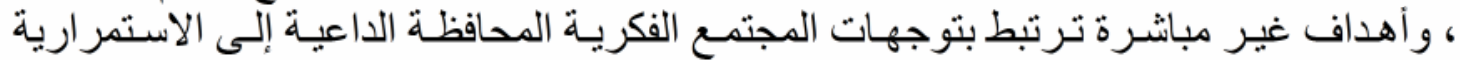

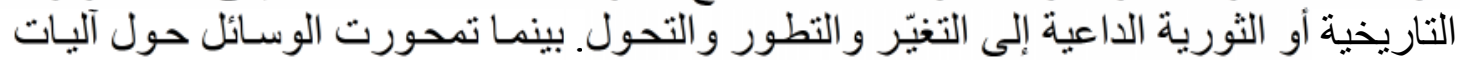

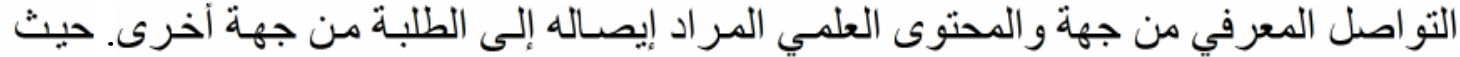

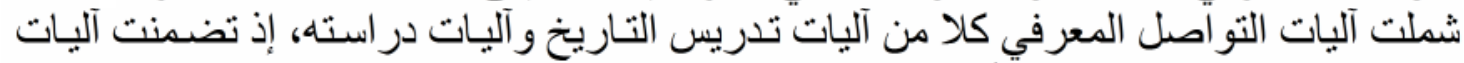

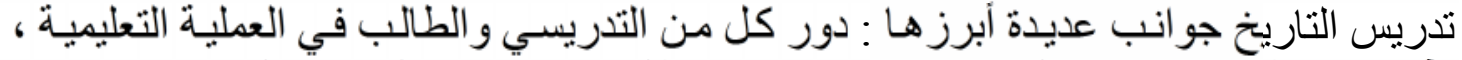

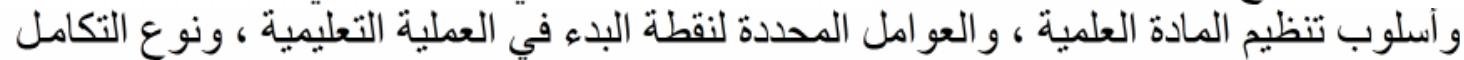

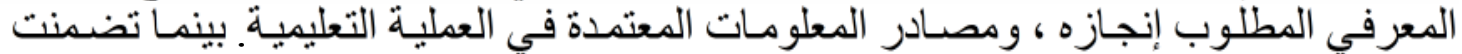

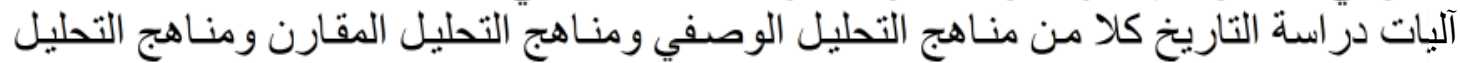

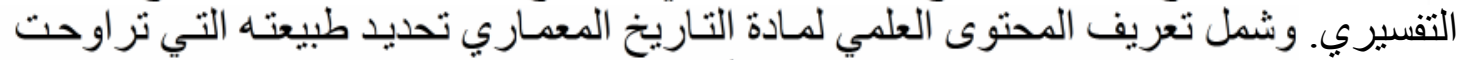

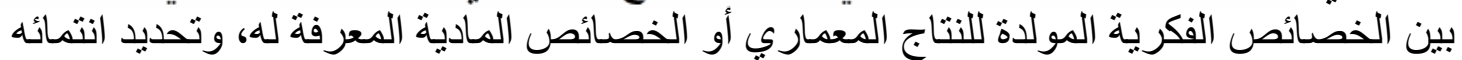

$$
\text { الزماني و المكاني. }
$$

\section{Teaching Architectural History _ Goals and Tools Study in Literatures of Architectural History Curriculums}

\section{Dhuha Abdul Ghani Abdul Aziz Assistant Lecturer in Department of Architecture/ Mosul University}

\begin{abstract}
The research deals with architectural history as one of the basic subjects in architectural teaching and learning, exploring both its' goals and tools. Its' goals concentrated directly on developing mental skills of students, and indirectly on either the concept of historical continuity or the concept of historical development. Its' tools can be defined by the procedures of knowledge communication which includes both procedures
\end{abstract}


of teaching and studying history, and the scientific content to be communicated to students.

Keywords: architectural history curriculums, procedures of teaching history, historical knowledge communication, historical knowledge content.

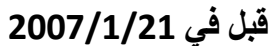

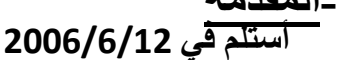

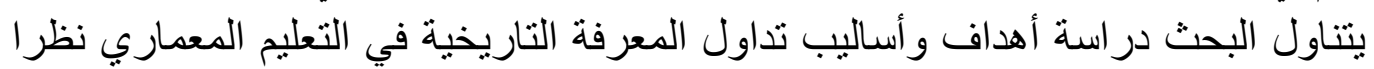

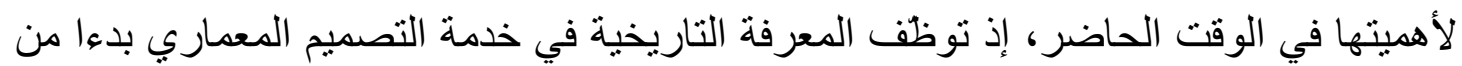

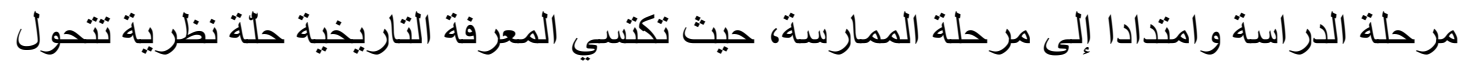

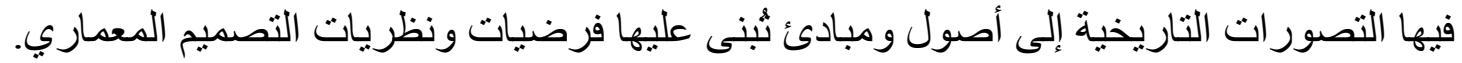

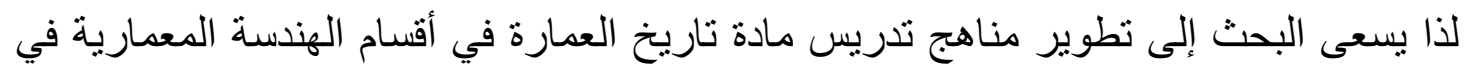

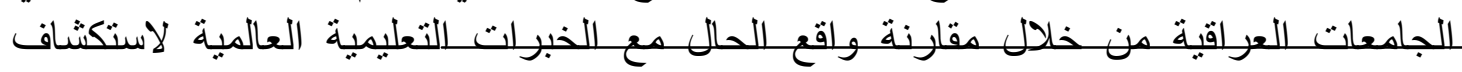

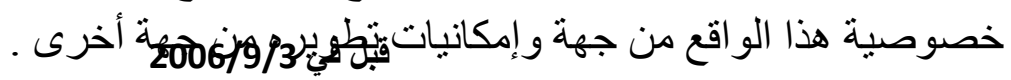

إذ بركز البحث على تحديد الأهداف وتعريف الوسائل المستخدمة في تدريس مادة تاريخ

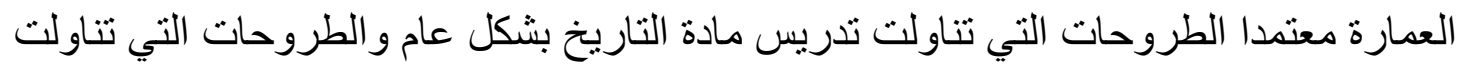
تدريس تاريخ العمارة بشكل خاص.

\section{Y- بأهداف تدريس مادة تاريخ العمارة}

يستعرض البحث أهداف تدريس مادة التاريخ بشكل عام ، ثم يتناول أهداف تدريس مـادة تاريخ

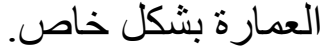

$$
\text { r. 1 أهداف تدريس مادة التاريخ بشكل عام }
$$

أنشارت دراسة الدكتور عبد الحميد السيد إلى أن تحديد الهدف يعدّ من مبادئ التدريس الجيد

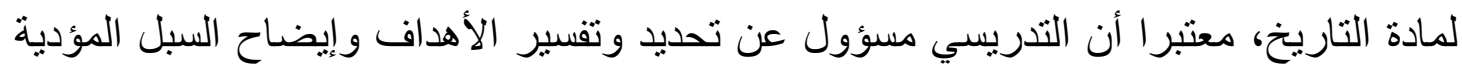

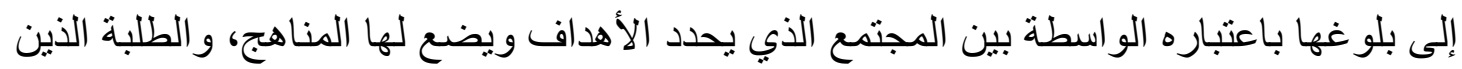

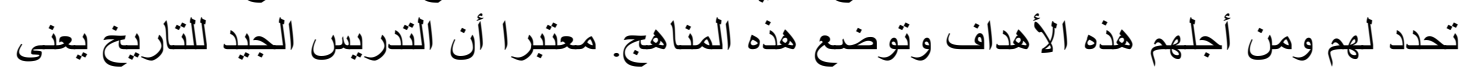

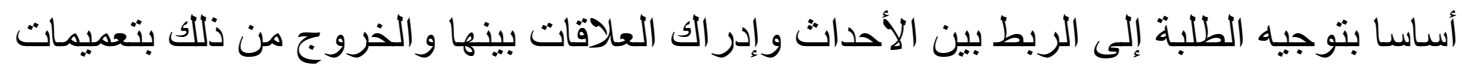
تعينهم على فهم المو اقف الجديدة وتفسير ها ، وتزيد قدرتهم على رؤية اتجاه التطور في المستقبل. 


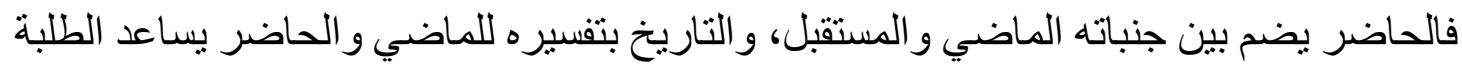

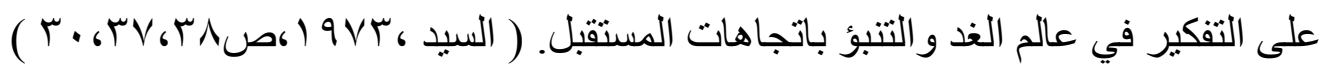

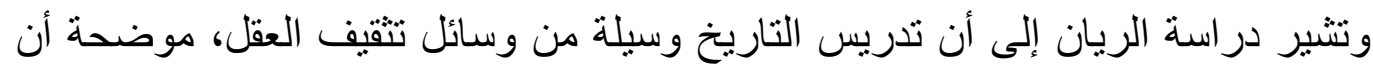

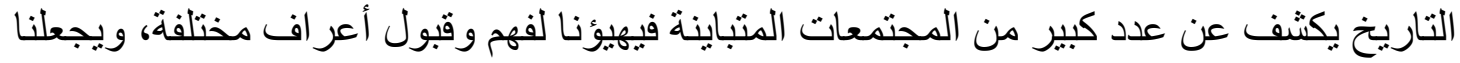

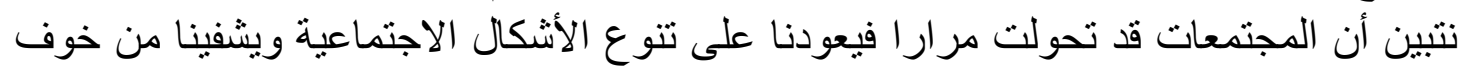

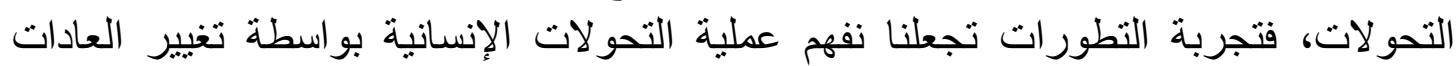

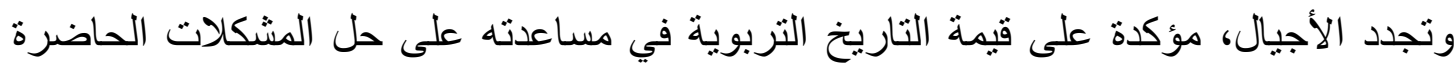

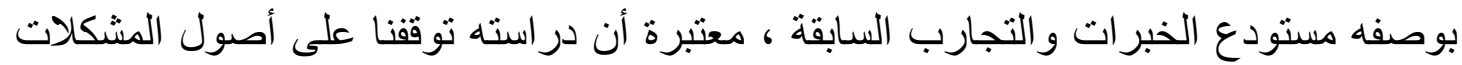

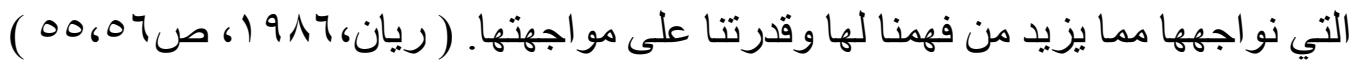

وتنشير دراسة اللقائي إلى أن أهداف تدريس التاريخ تستند إلى محورين رئيسيين هما :

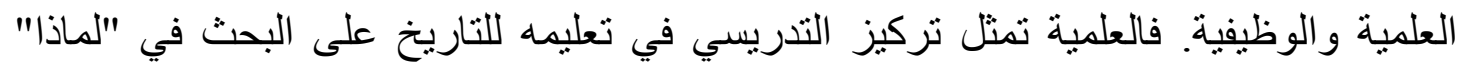

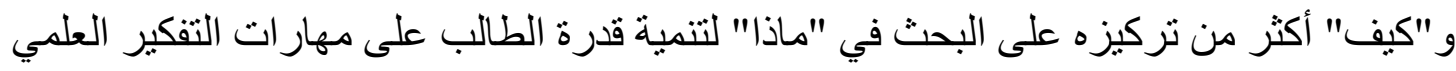

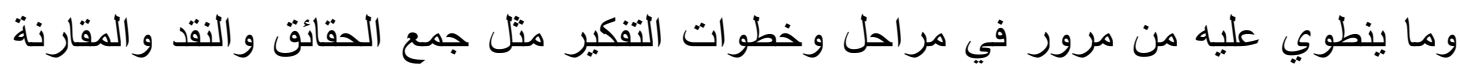

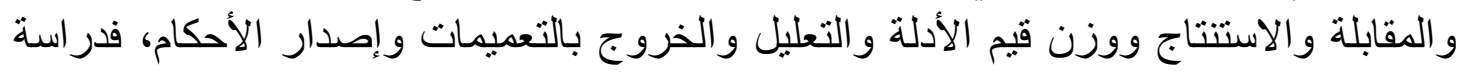

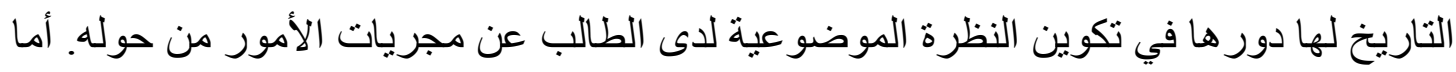

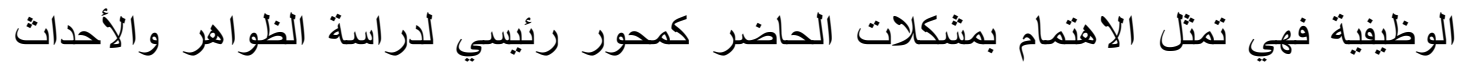

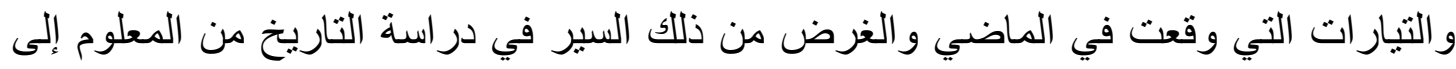

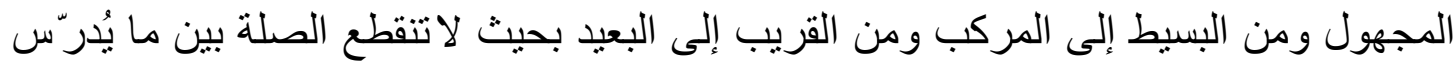

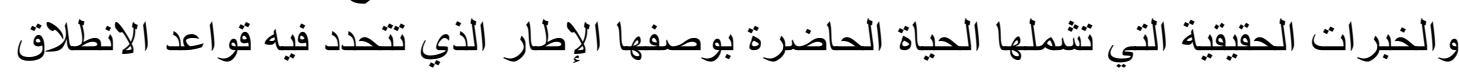

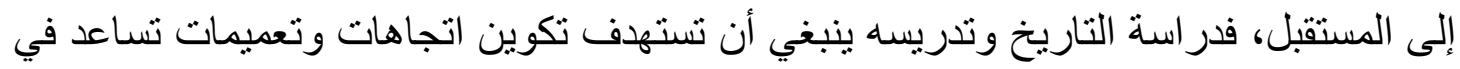

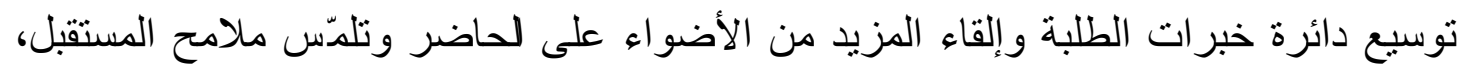

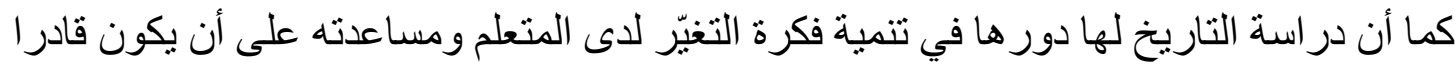

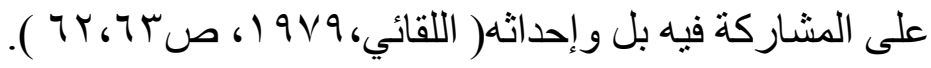

مما تقدم يتضح أن أهداف تدريس مادة التاريخ تتمحور حول جانبين الأول مباثر يتمثل بتطوير

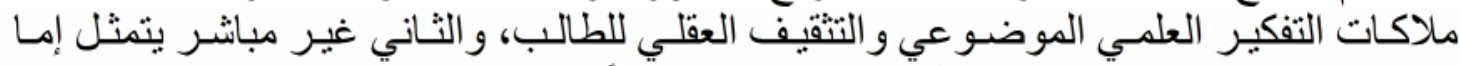

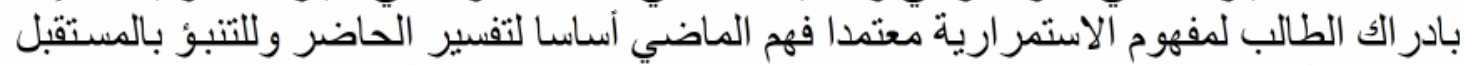

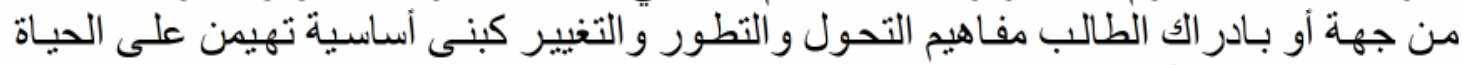

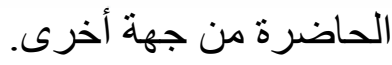

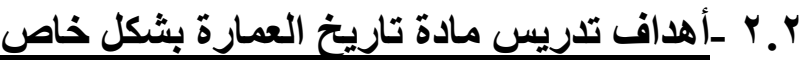

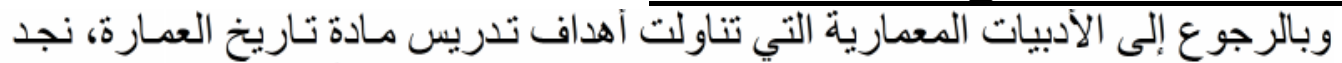

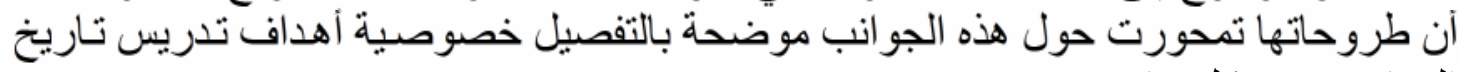

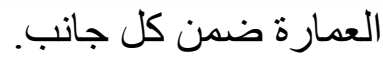

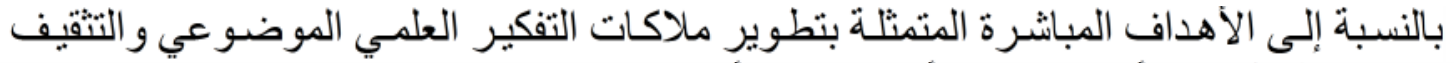

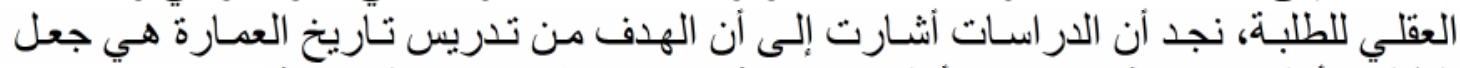

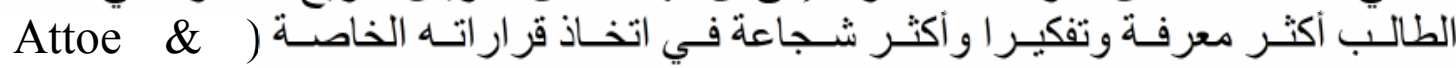




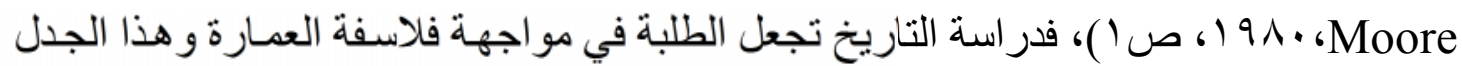

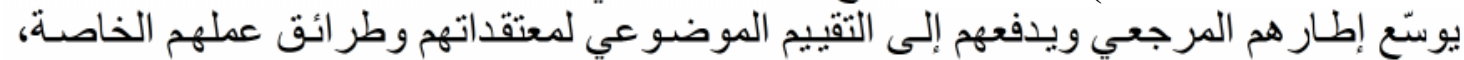

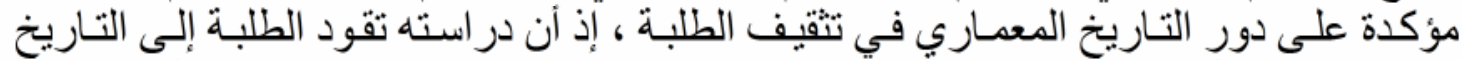

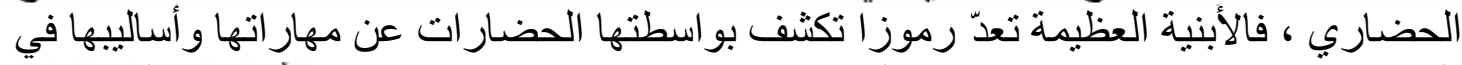

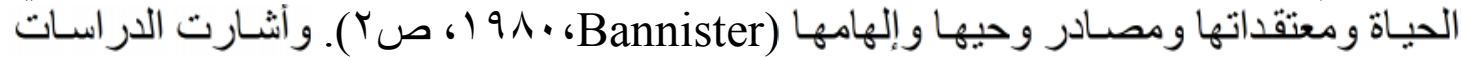

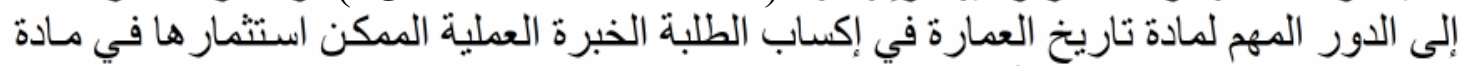

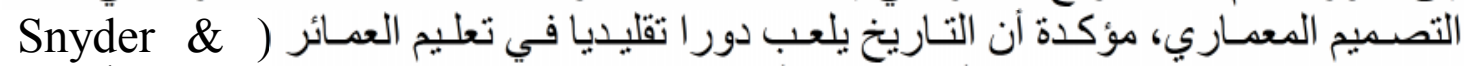

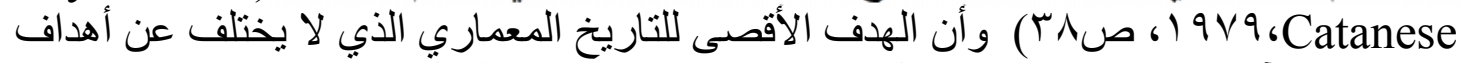

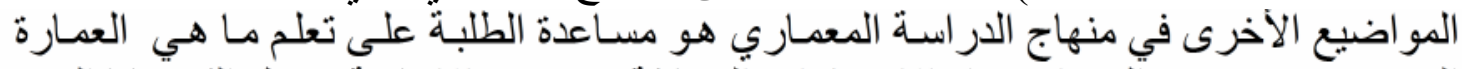

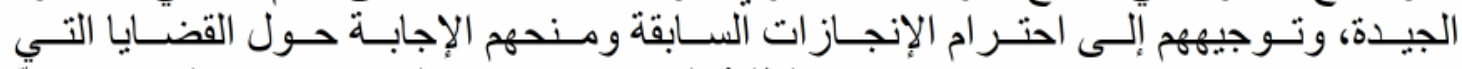

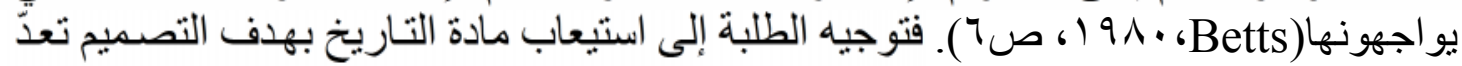

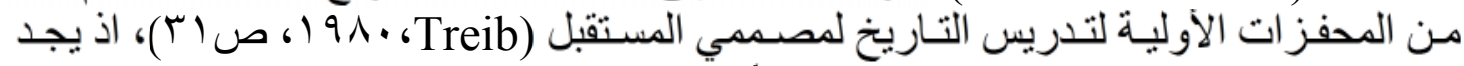

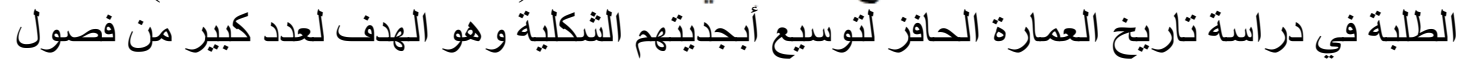

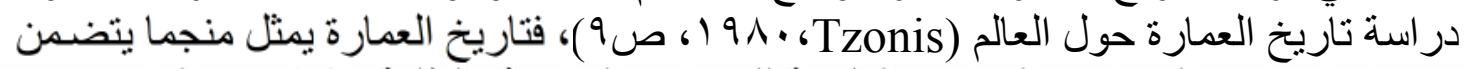

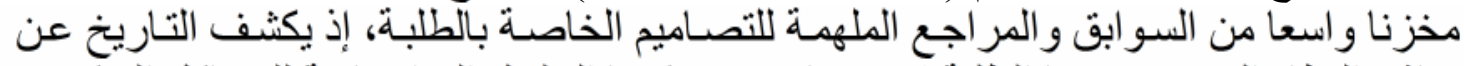

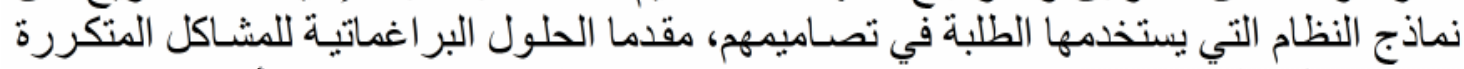

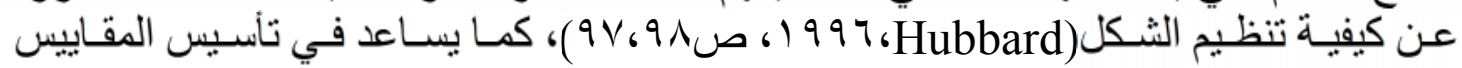

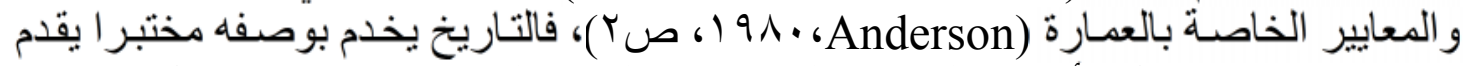

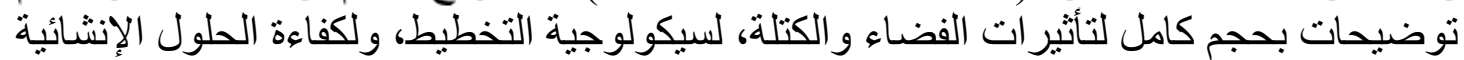

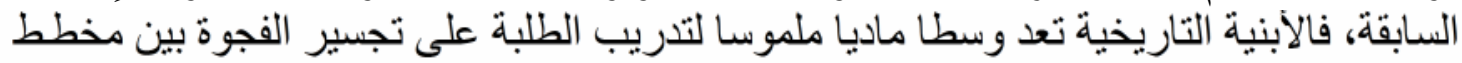

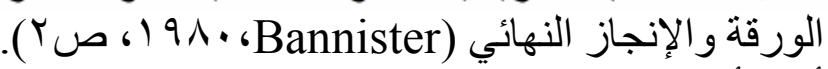

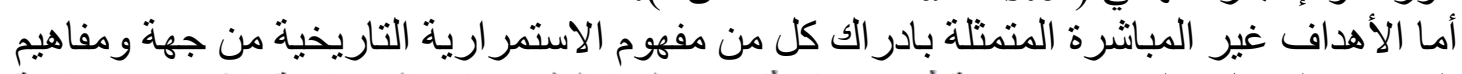

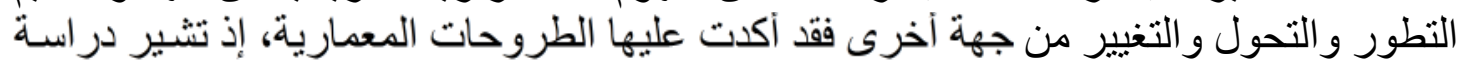

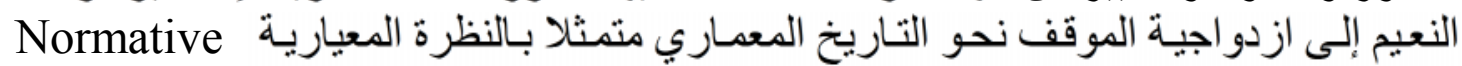

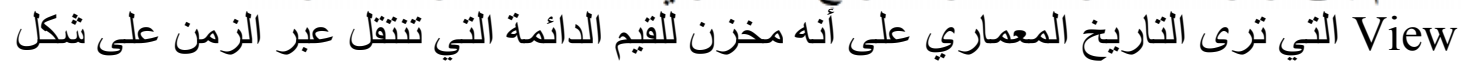

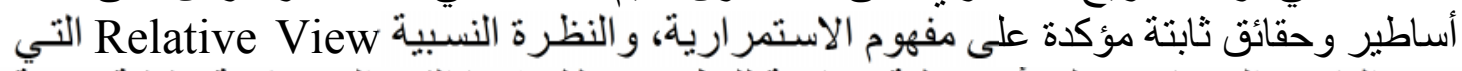

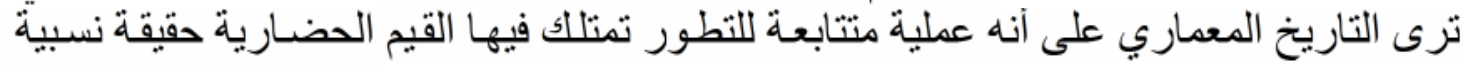

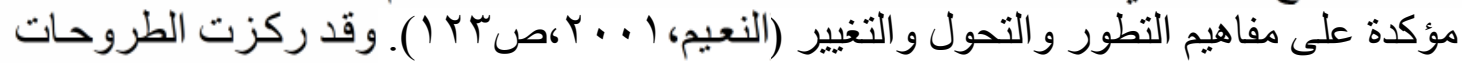

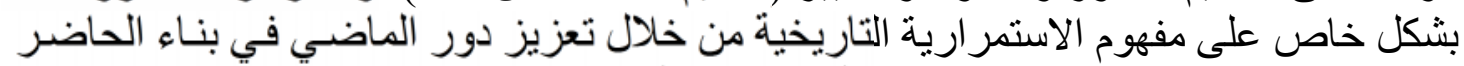

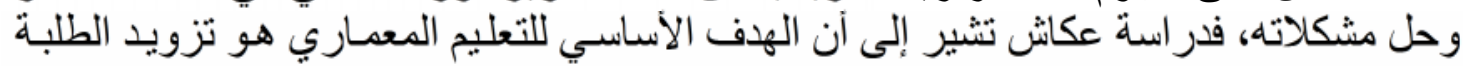

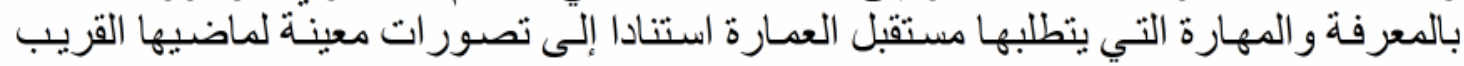

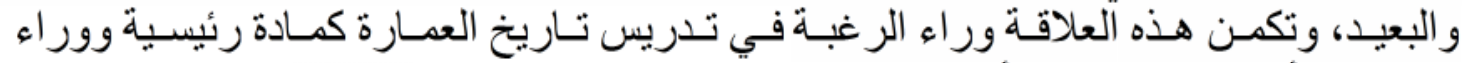

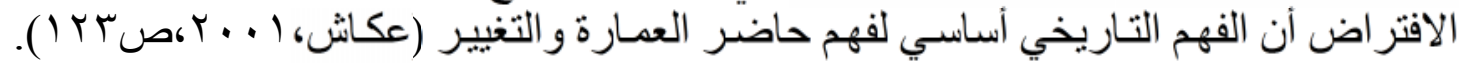

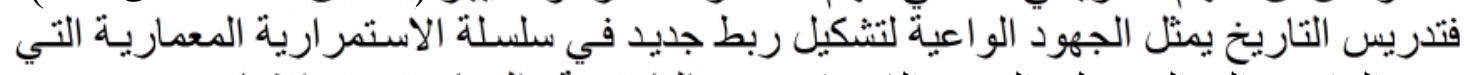

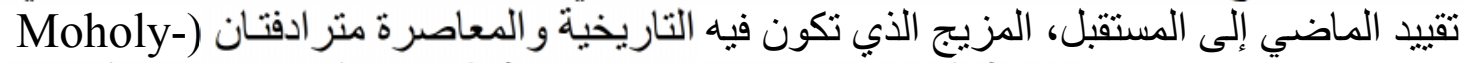

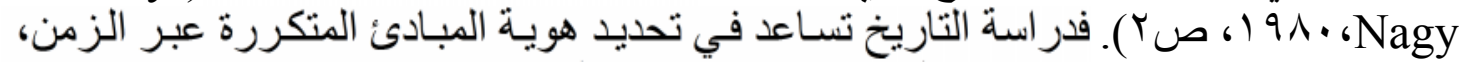

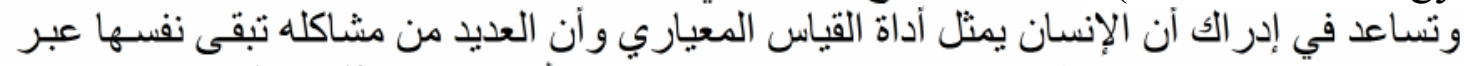

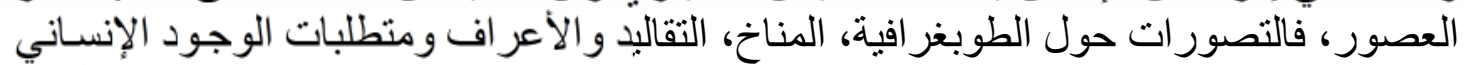

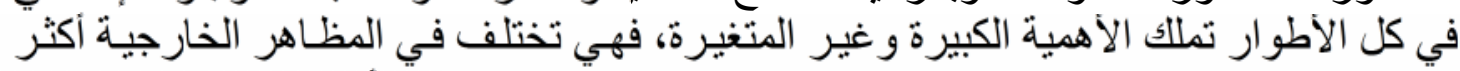

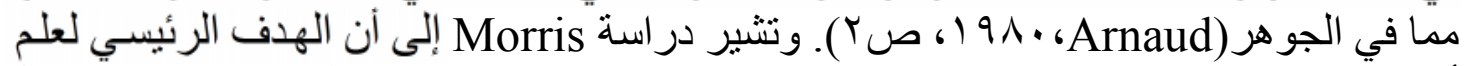

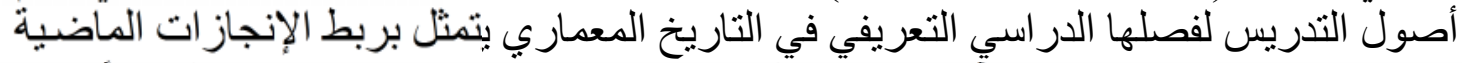

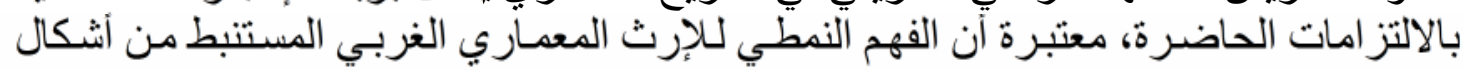


الإبنية التاريخية يمكن المعماري المستقبلي من المشـاركة في دعم هذه التقاليد خـلال الاستجابة

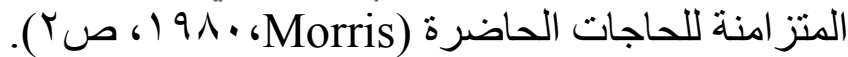

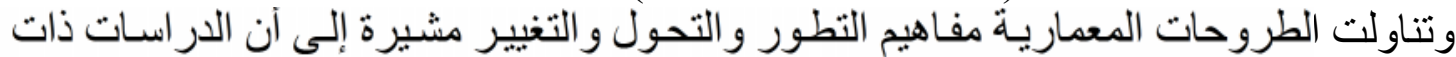

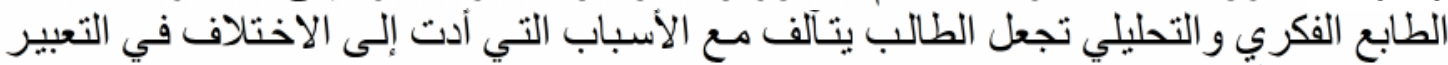

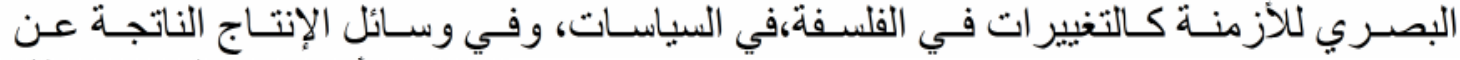

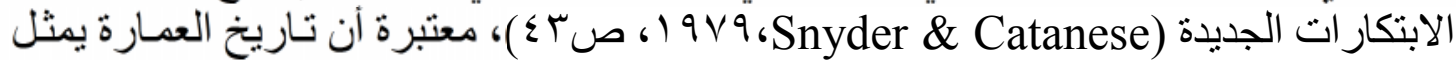

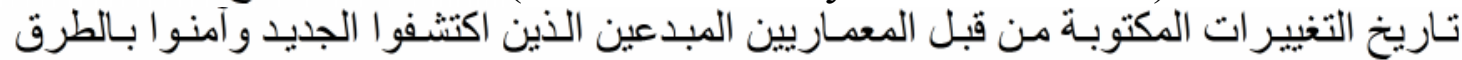

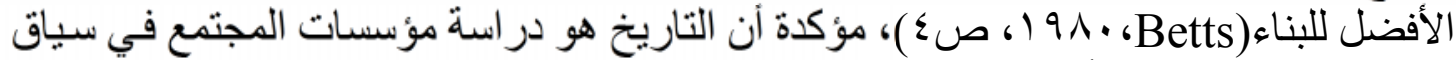

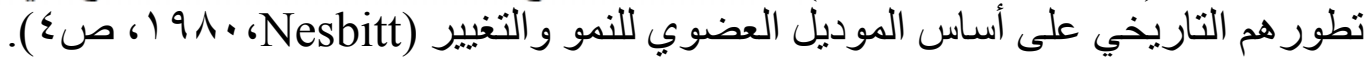

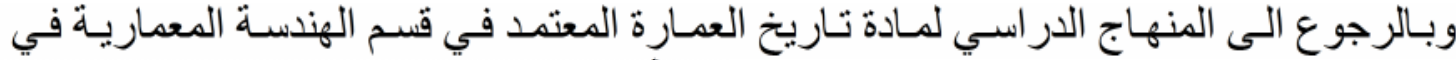

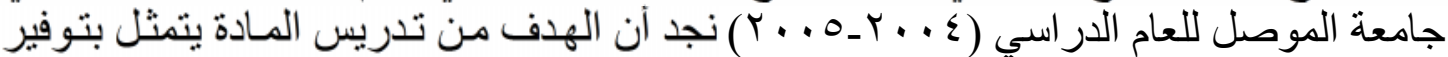

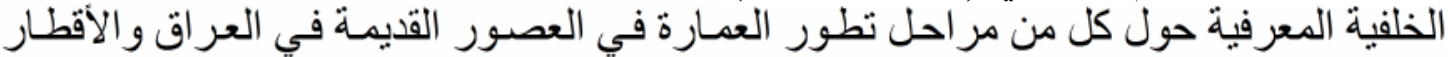

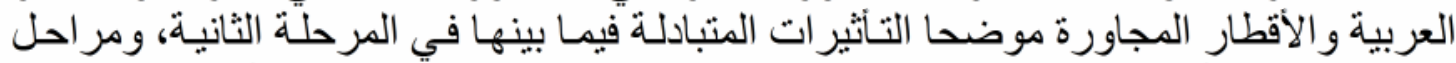

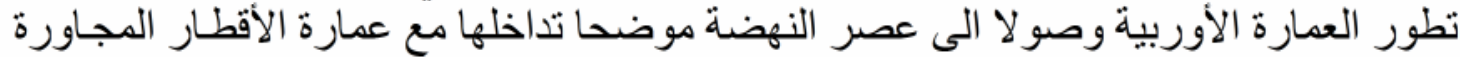

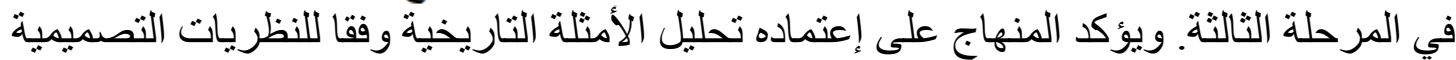

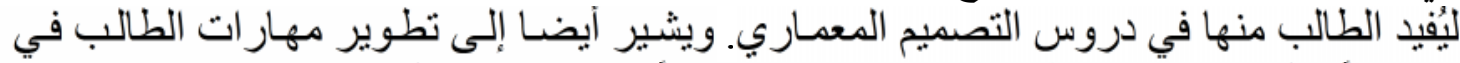

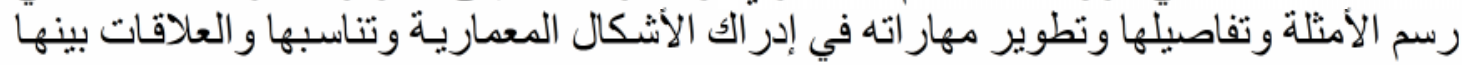
إضافة إلى تدريب الذاكرة الصورية للطالب.

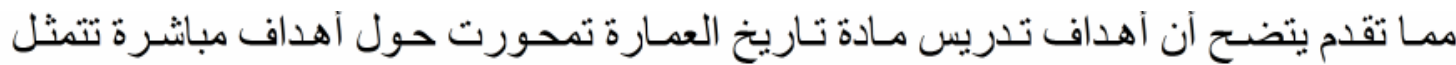

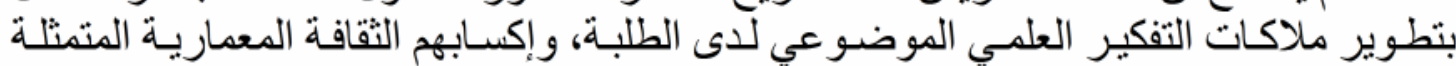

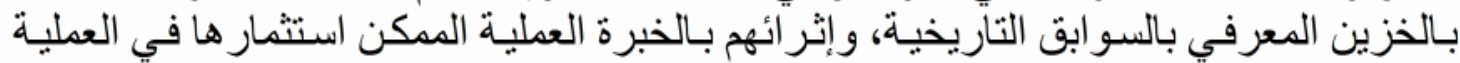

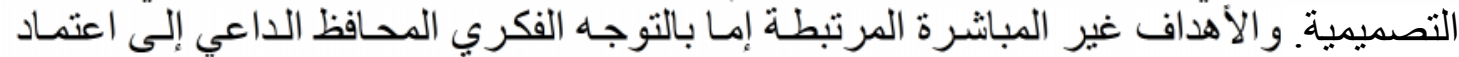

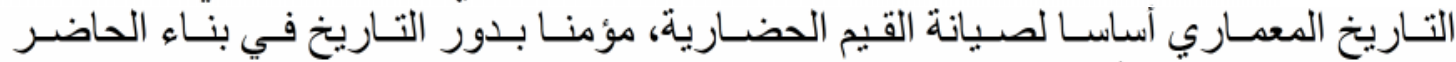
و واستكثاف المستقبل، أو المرتبطة بالتوجه الفكري الثوري الهادف إلى الوصول الهئل إلى الفهم النقدي و والحاسم لمعنى التطور الحضاري.

\section{بـا-الوسائل المستخدمة في تلدريس مادة تاريخ العمارة}

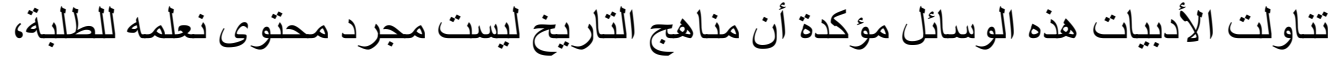

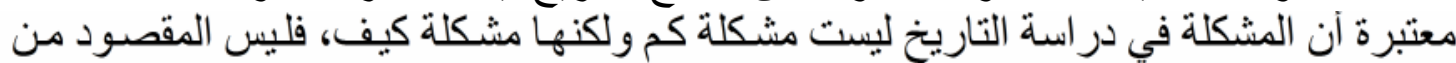

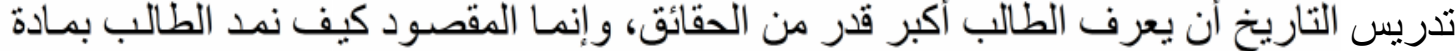

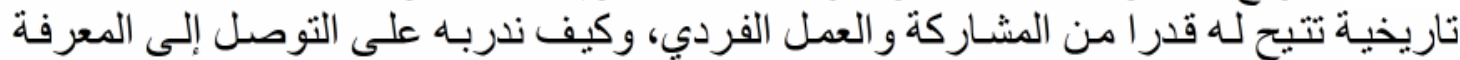

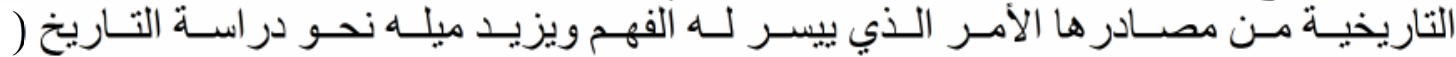

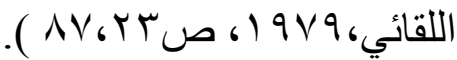

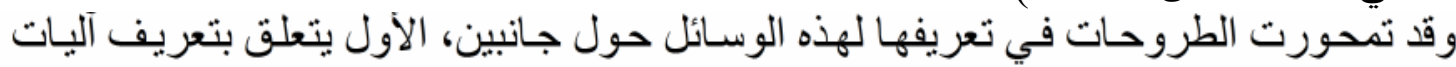
التو اصل المعرفي، بينما يتعلق الثاني بنعريف المحتوى العلمي المر اد إيصاله إلى الطلى الطلبة.

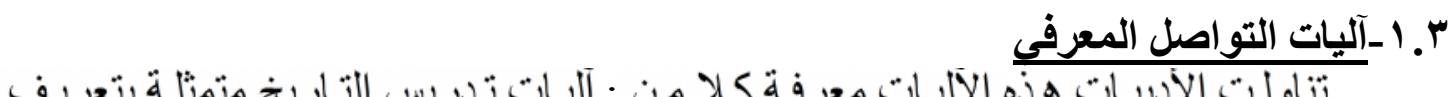

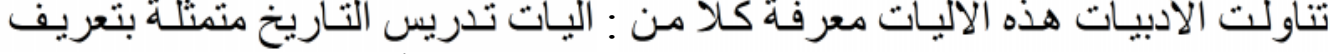

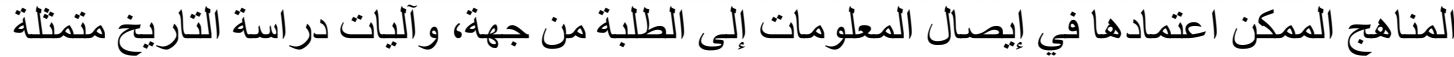

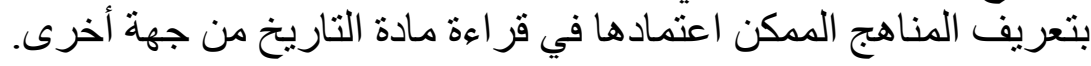




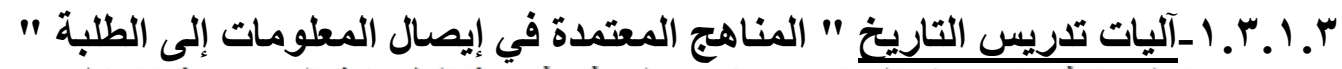

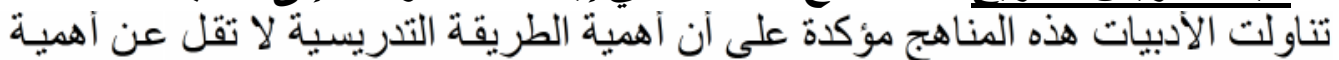

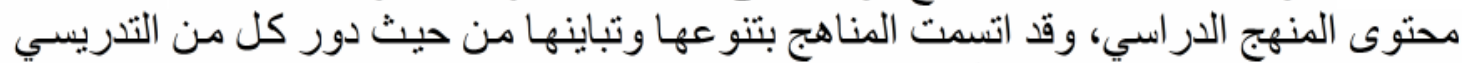

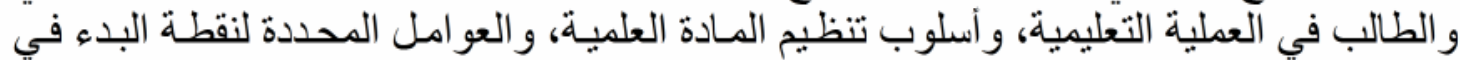

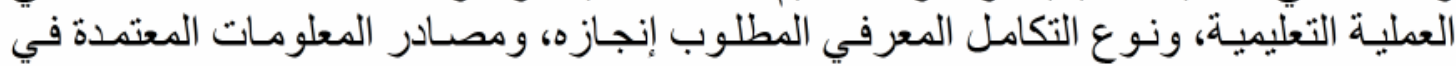

أولا : دور كل من التّريسى والطالب في العملية التعليمية

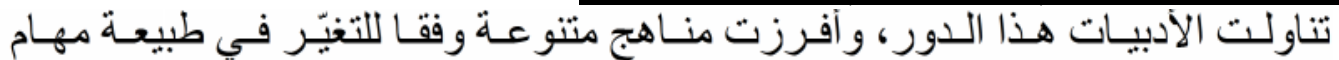

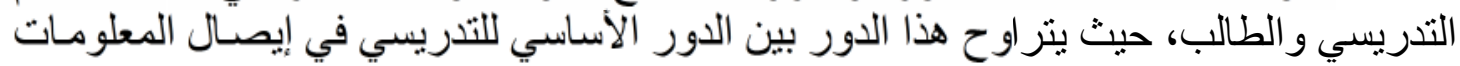

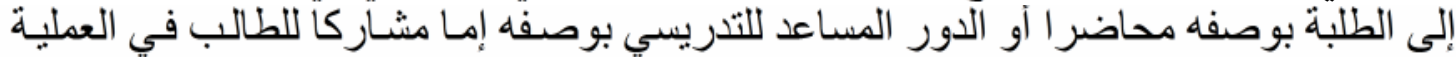
التعليمية أو مشرفا عليه. - النيه بالنسبة إلى الدور الأساسي للتدريسي فيتمثل في طريقة المحاضرة التي تتضمن إلقاء المعلومات

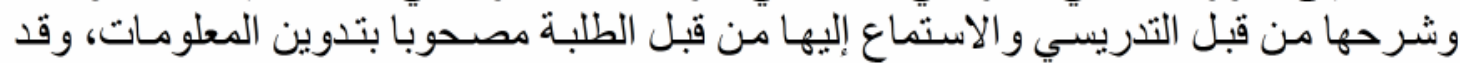

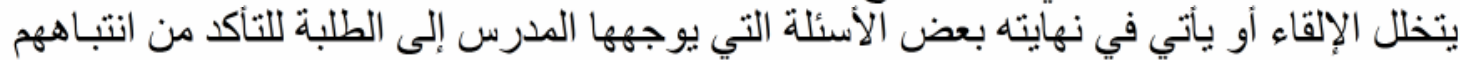

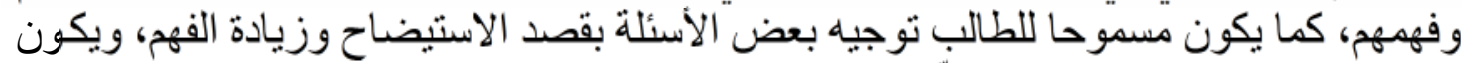

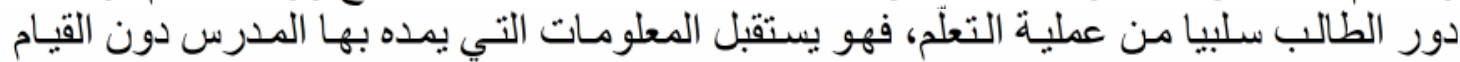

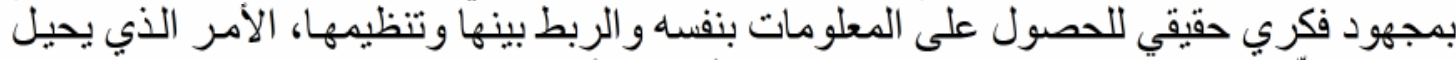

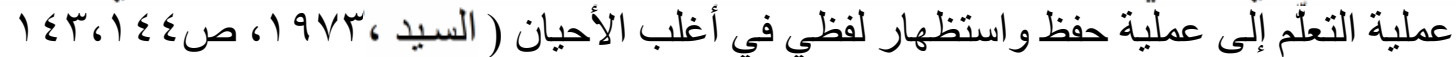

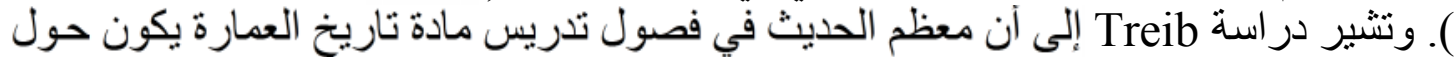

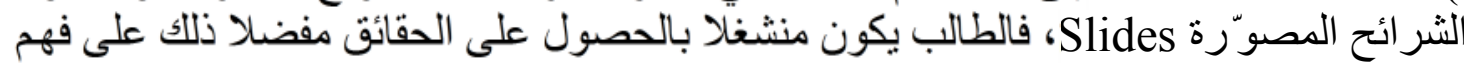

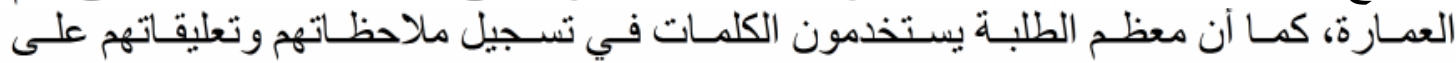

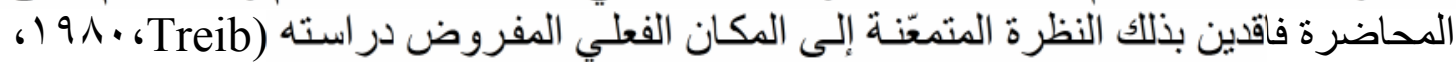

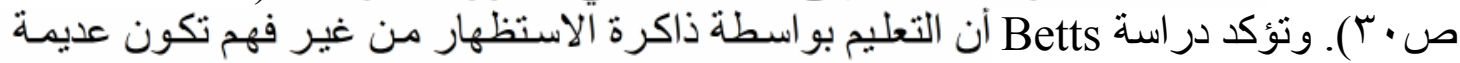

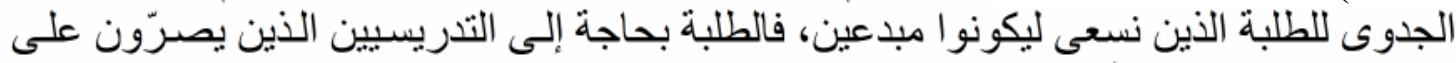

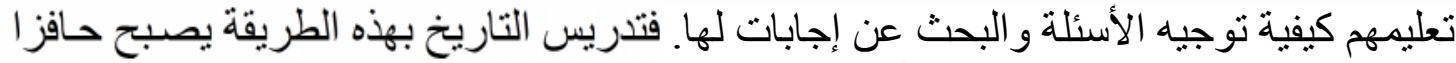

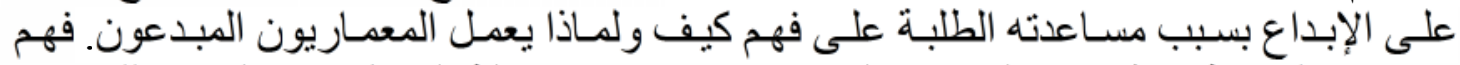

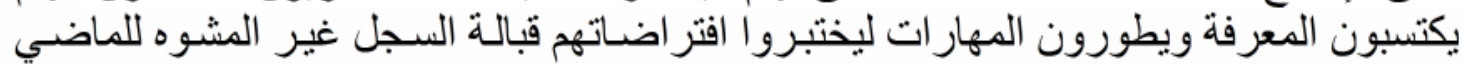

( Betts) ما الدور المساعد للتنريسي بوصفه مشاركا للطالب في العملية التعليمية فيظهر جليا في طريقة

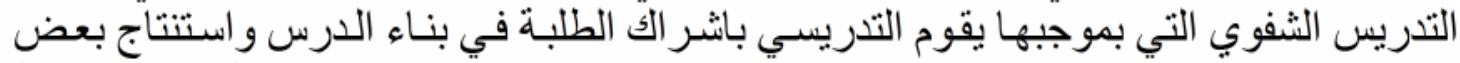

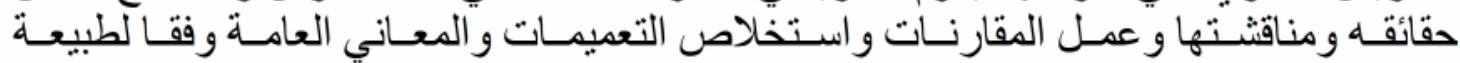

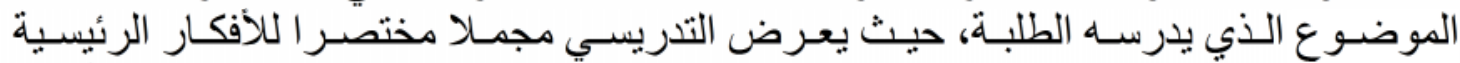

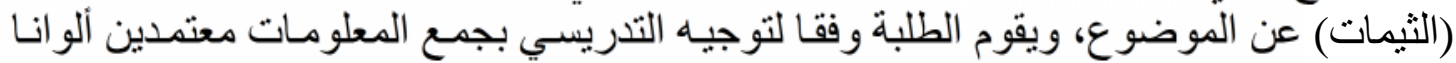

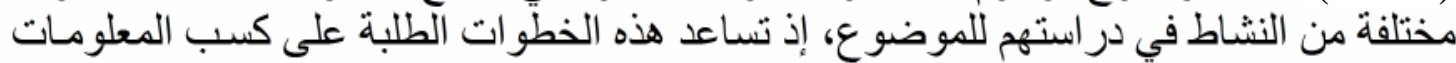

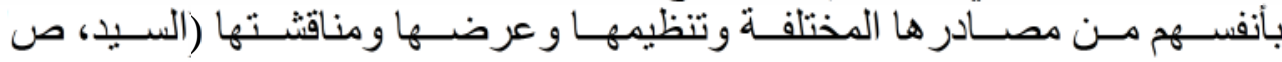
( Lyndon) (

ويتجلى اللدور المســاعد للتنريسي بوصـفه مشـرفا على الطالب في كـلا طريقتي التعيينـات

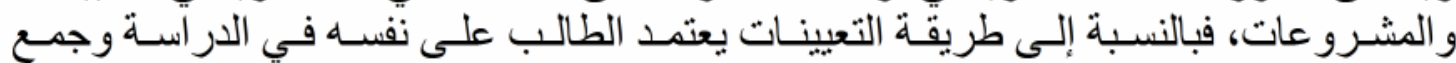

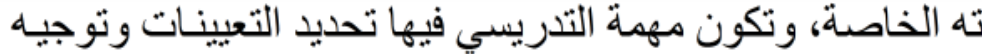

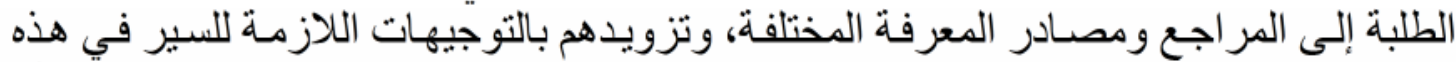

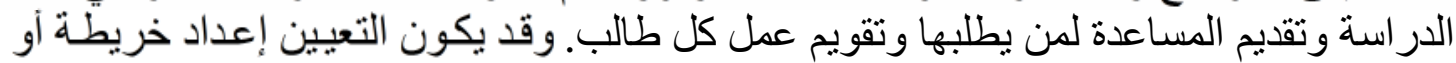




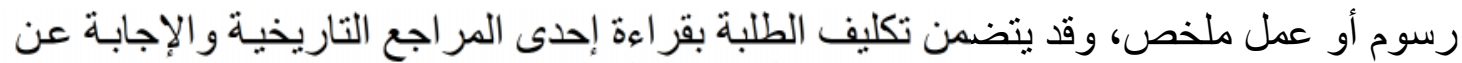

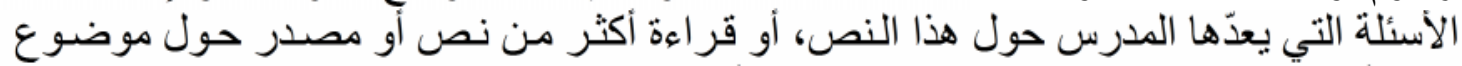

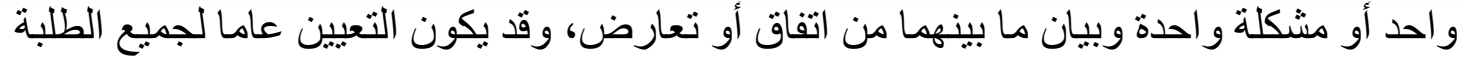

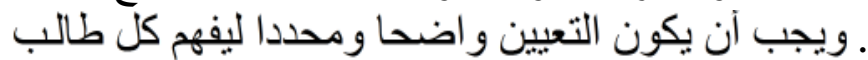

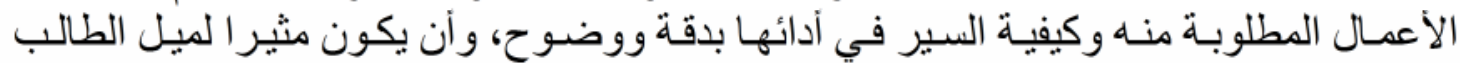

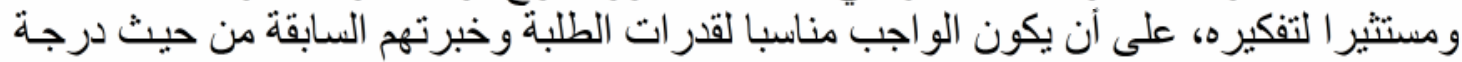

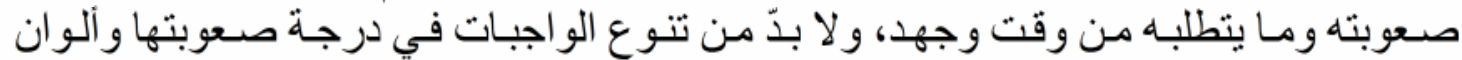

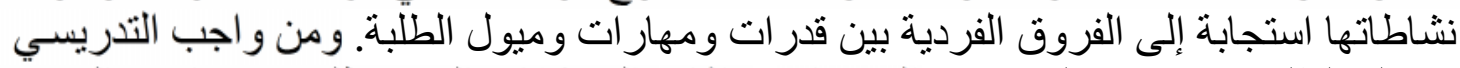

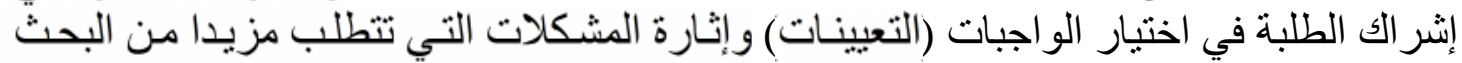

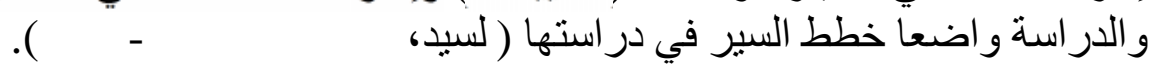

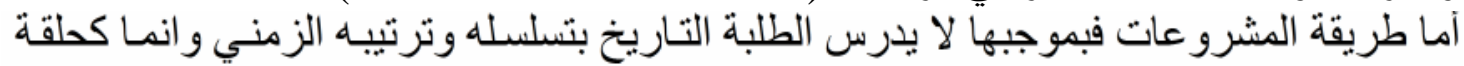

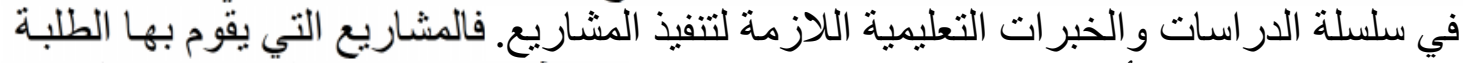

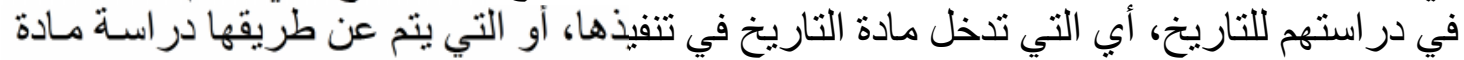

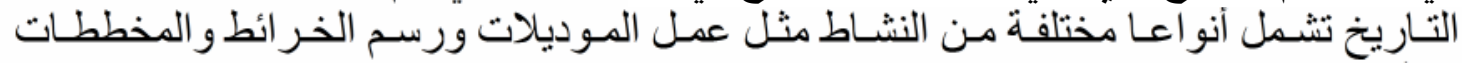

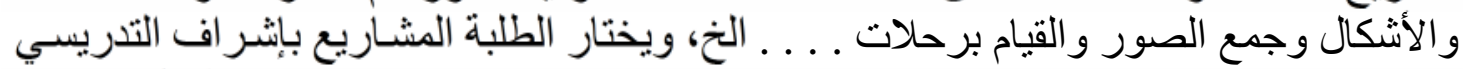

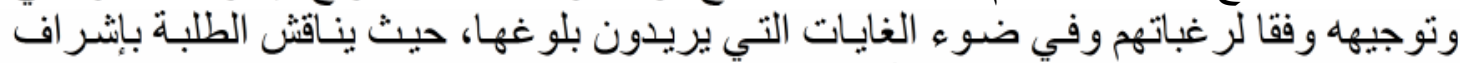

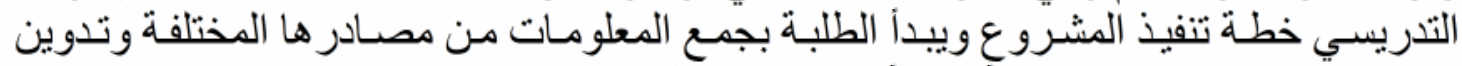

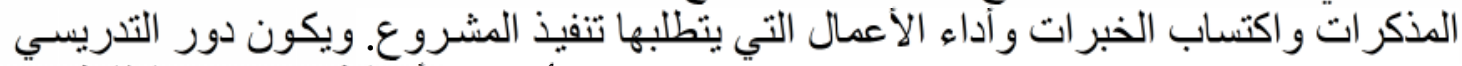

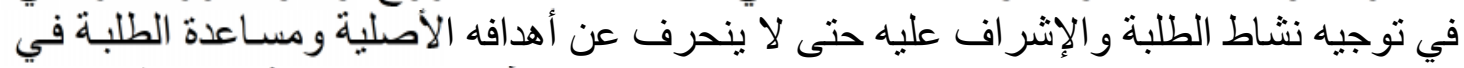

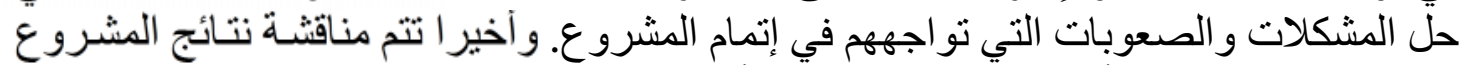

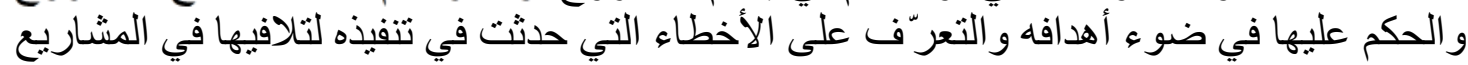

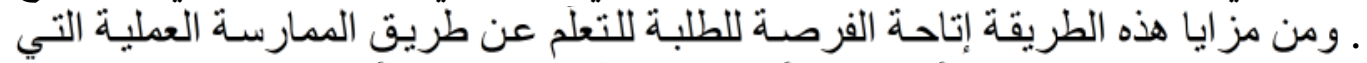

تساعد على تر ابط المعلومات و الأفكار في أذهان الطلبة وتكاملها، إذ أنهم لا يدركون الحقائق القيق

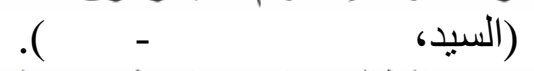

إنّ التعليم المثمر لتاريخ العمارة بستلزم التفاعل بين التدريسي والطالب باستخدام طرق تُعلئيمية

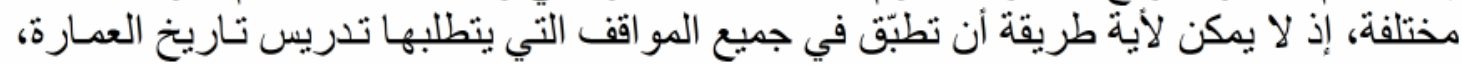

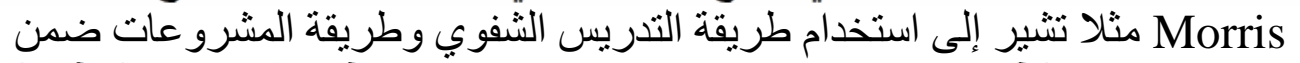

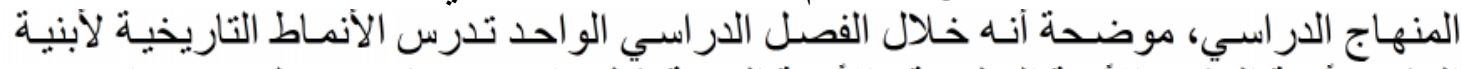

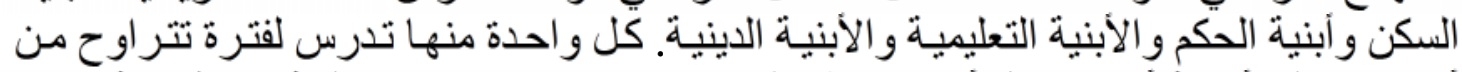

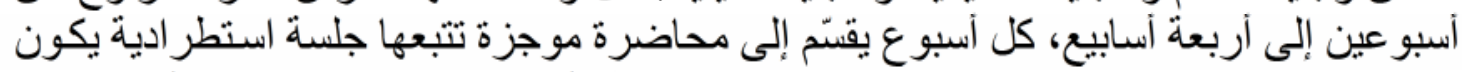

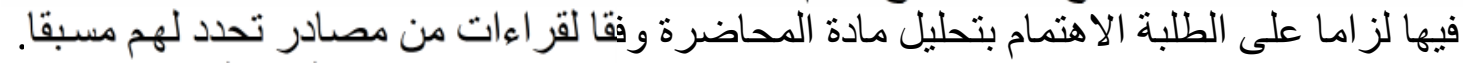

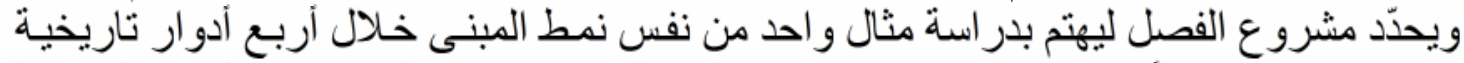

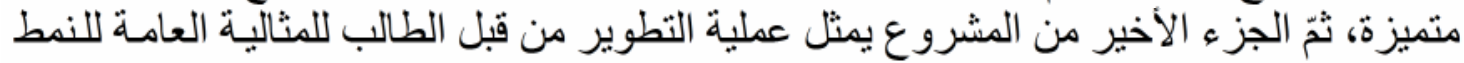

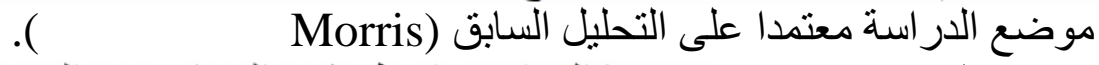

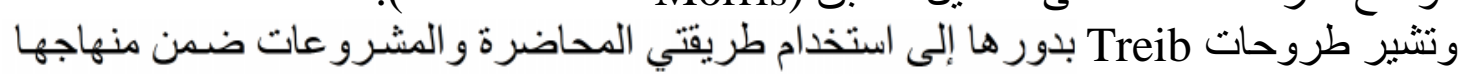

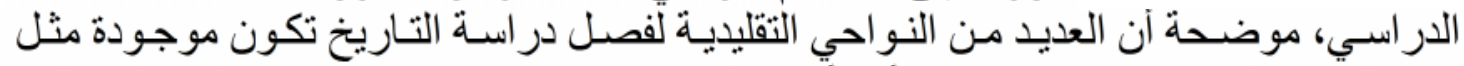

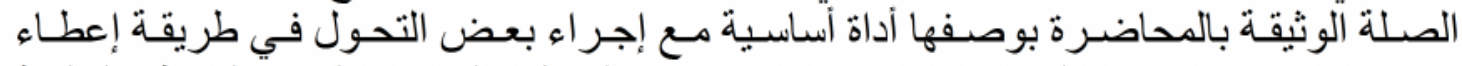

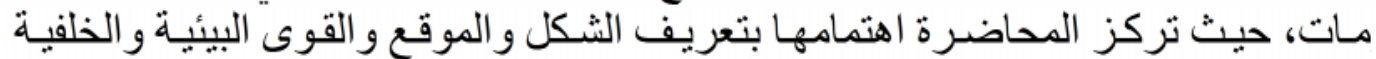

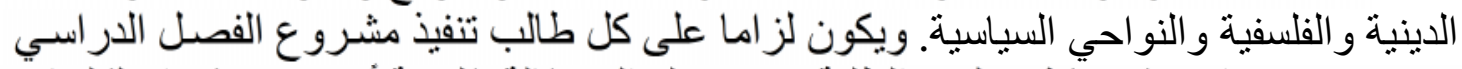

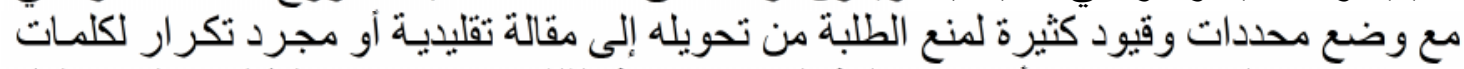

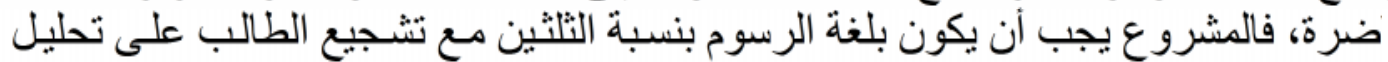

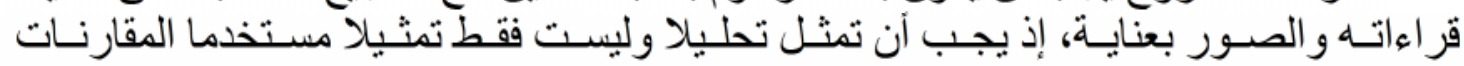
الحضارية، فالرسوم تمتلك المواصفات التي تفتقر إليها الكلمات، بالنسبة إلى رسوم التمثيل يجب التبل 


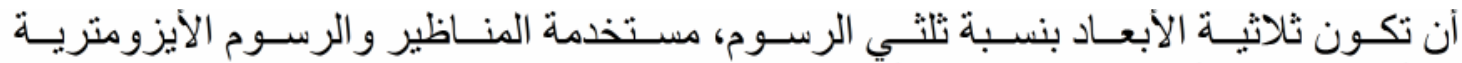

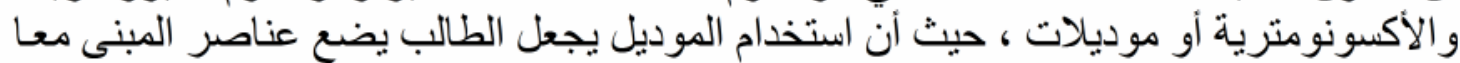

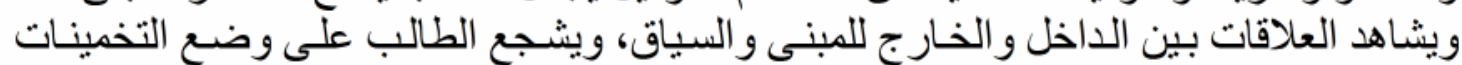

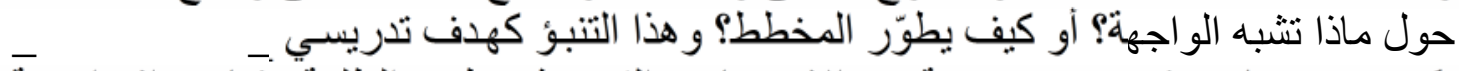

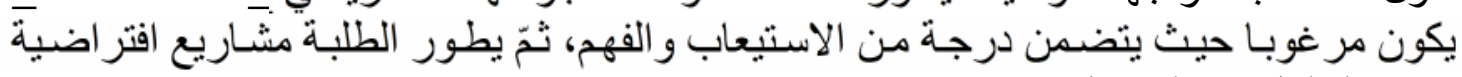

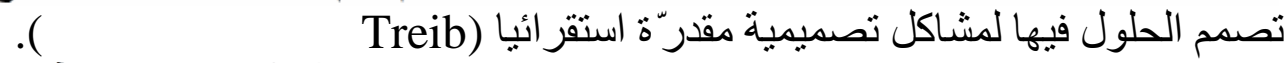

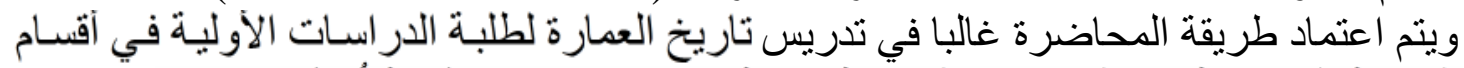

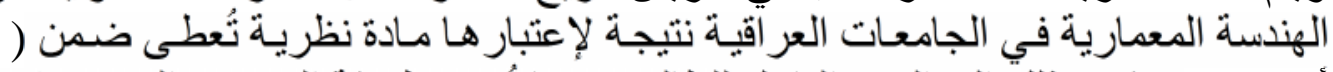

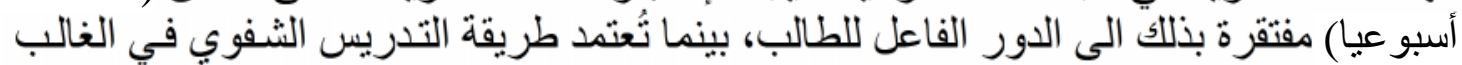

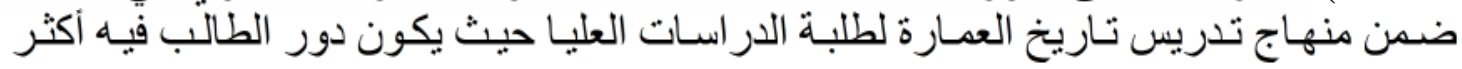
فاعلية.

يتضح مما تقدّم تباين دور كل من التدريسي والطالب في العملية التعليمية وفقا لطريقة التـدريس

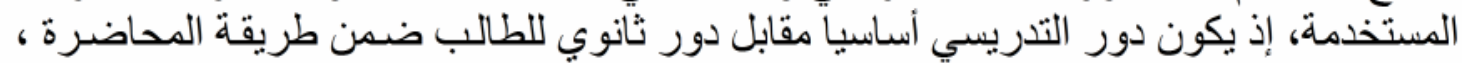

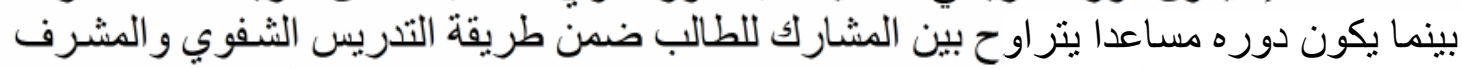

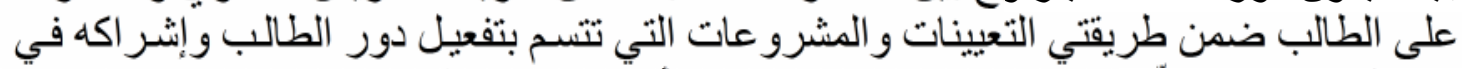

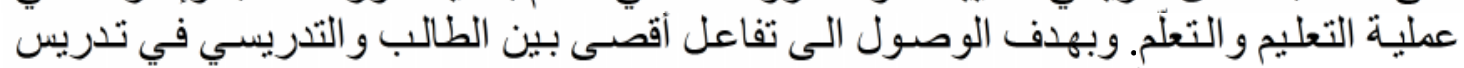

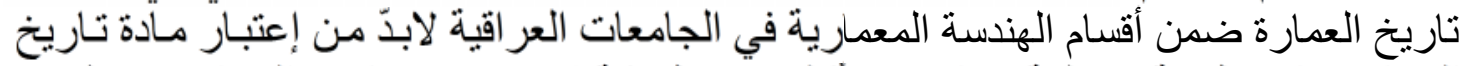

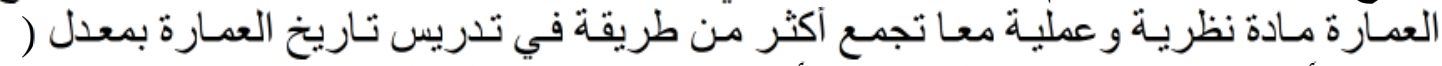
ساعات أسبو عيا) لإعطاء هذه المادة دور الكبر ضمن فن منهاج آلتعليم المعماري.

ثانيا: أسلوب تنظيم المادة العلمية

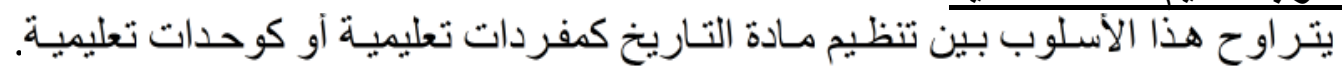

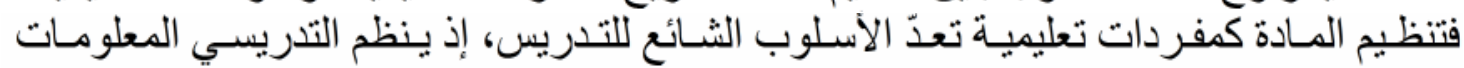

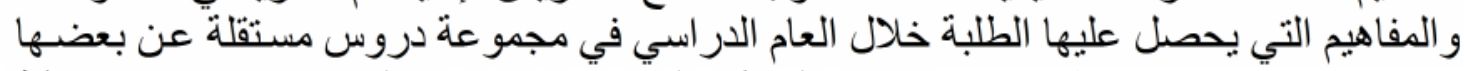

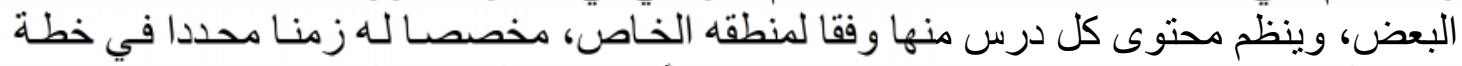

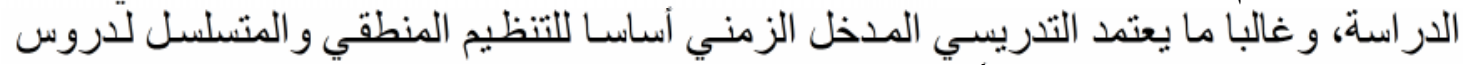

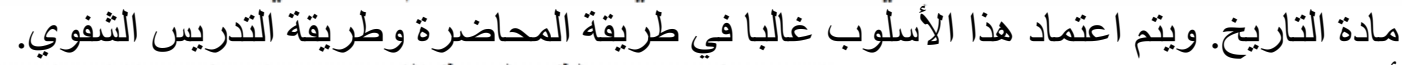

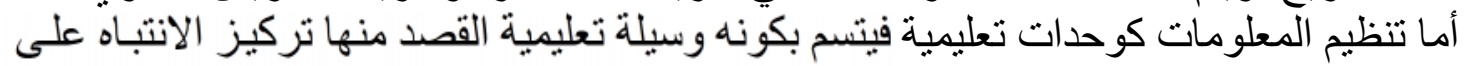

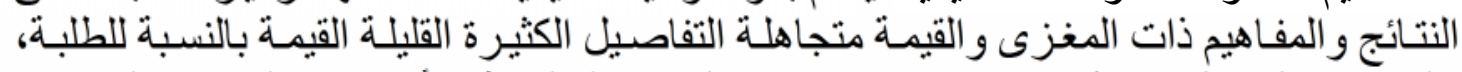

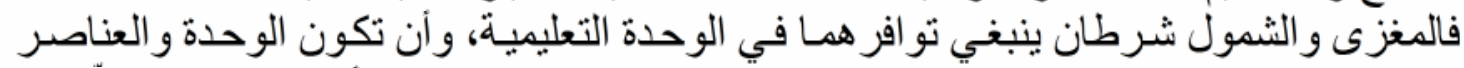

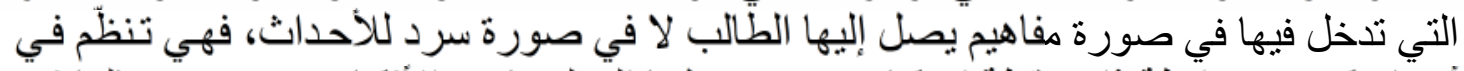

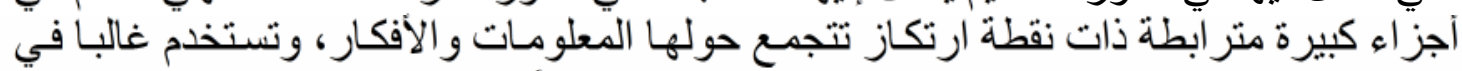

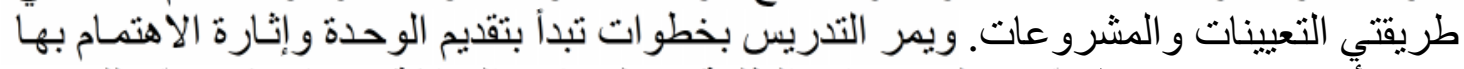

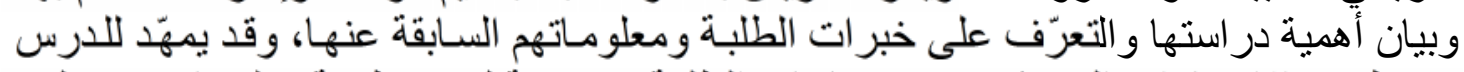

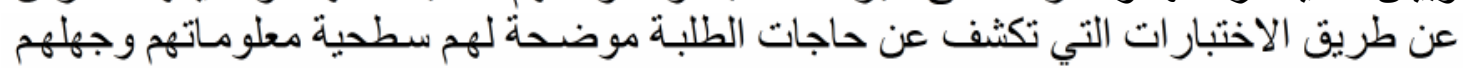

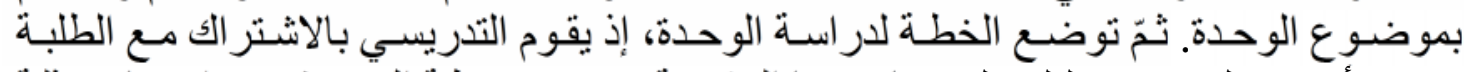

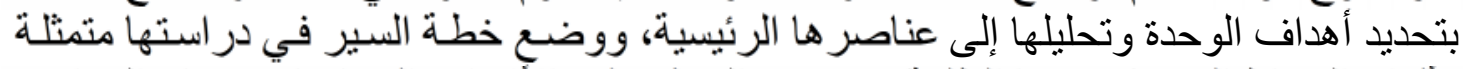

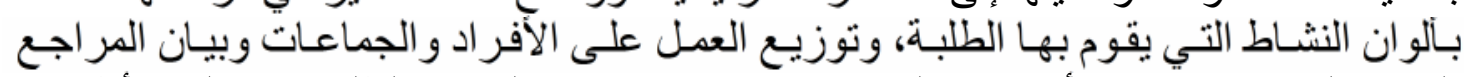

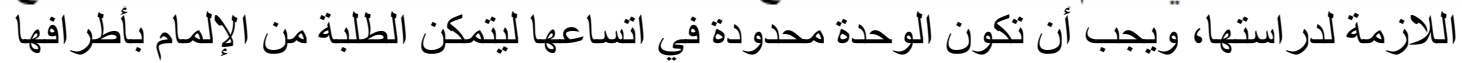

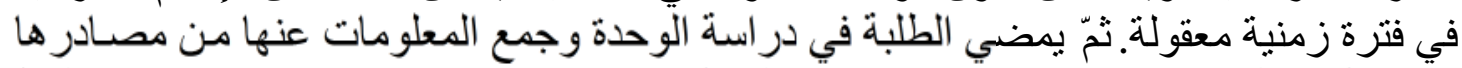

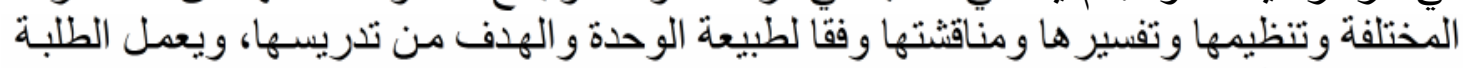

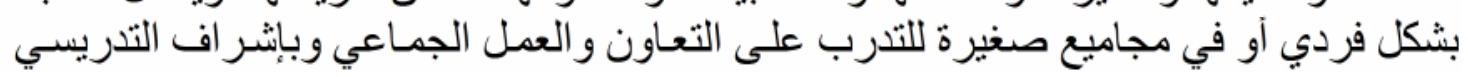




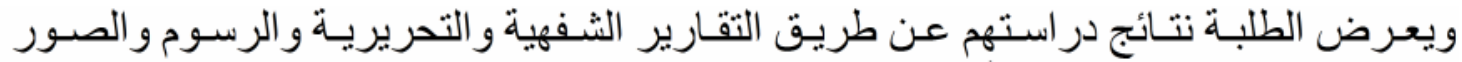

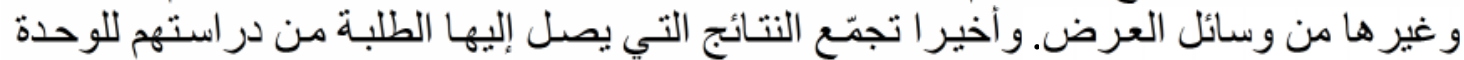

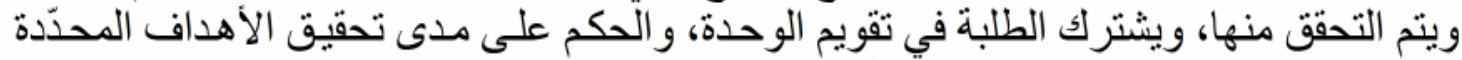

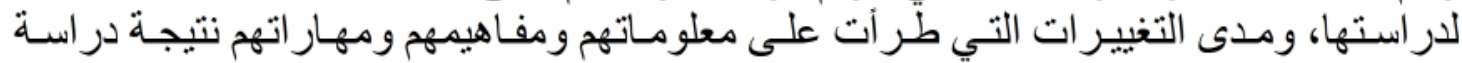

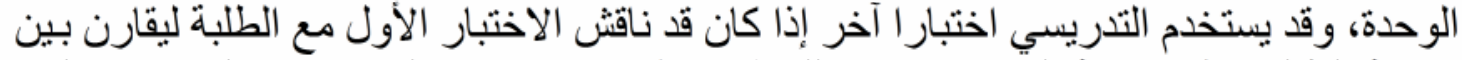

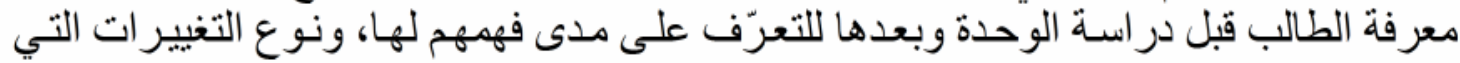

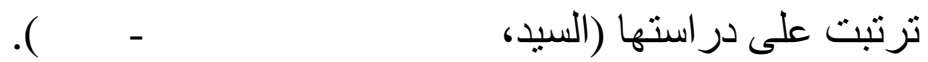

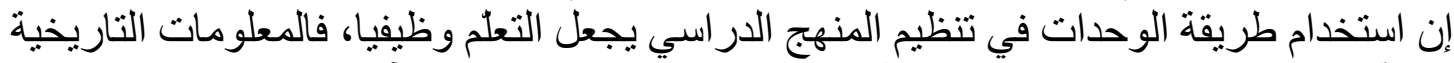

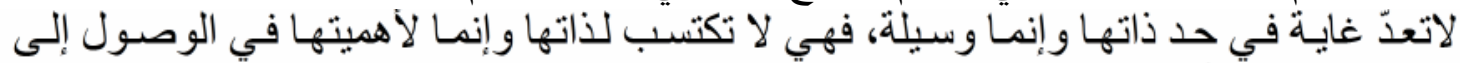

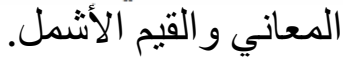

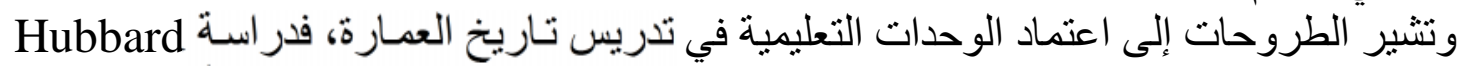

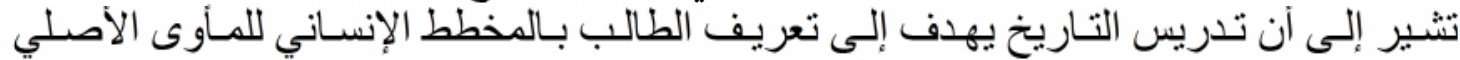
Chareton

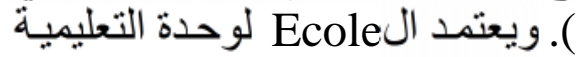
Hubbard)

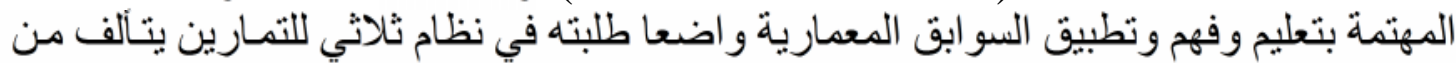

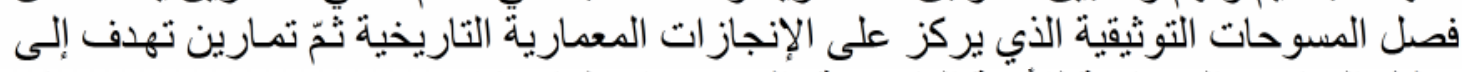

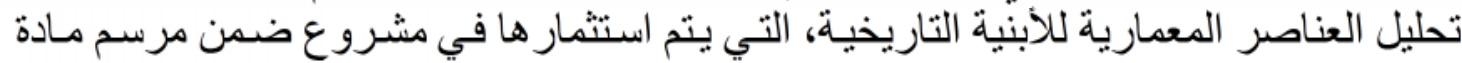

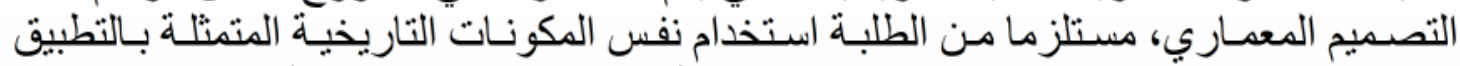

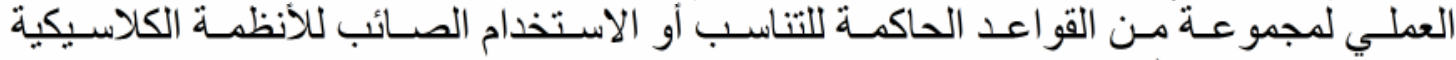

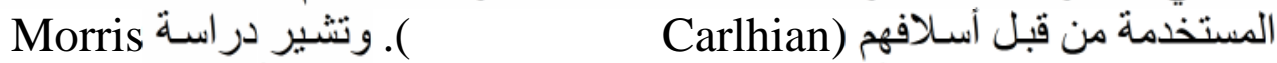

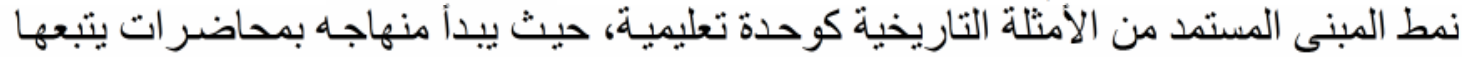

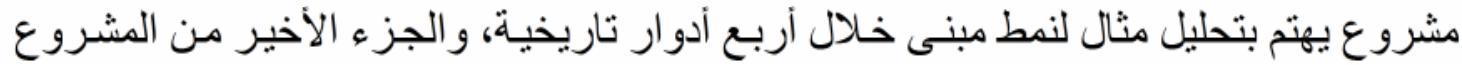

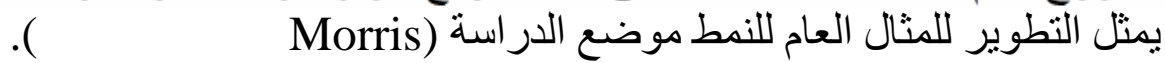

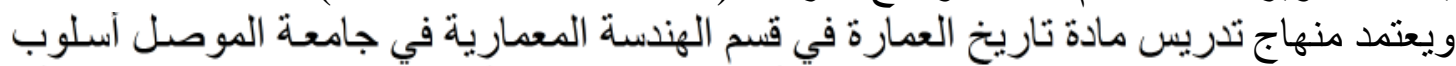

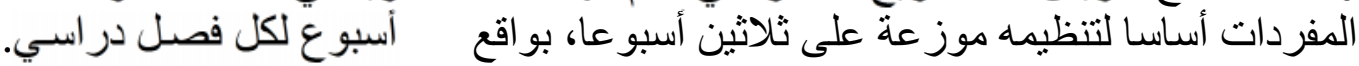

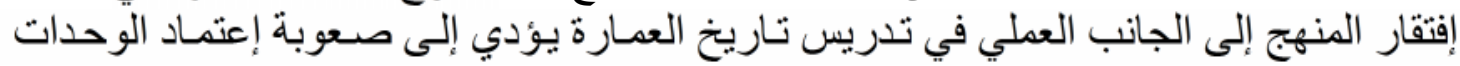
فة النظرية في قضايا عملية.

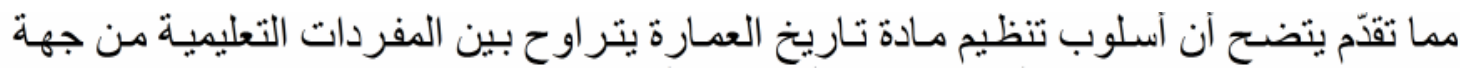

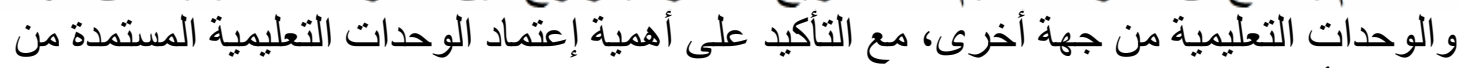
تحليل الأمثلة التاريخية وتوظيفها في مشّاريع عملية.

ثالثا: العوامل المحددة لنقطة البدع في العملية التعليمية

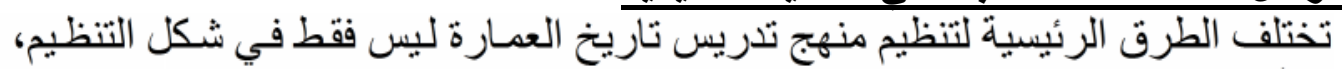

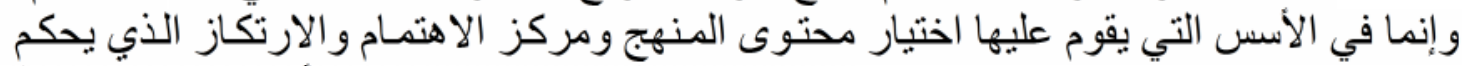

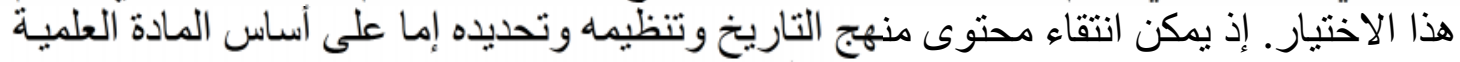

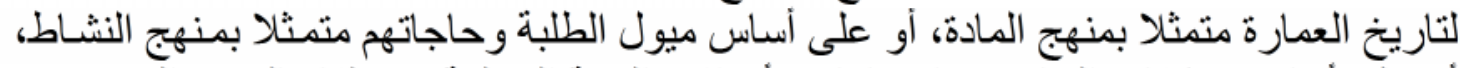

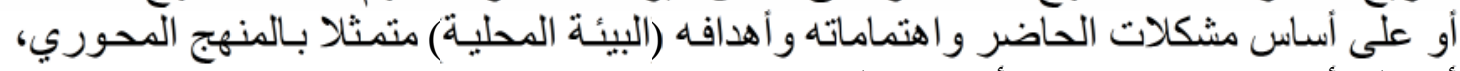

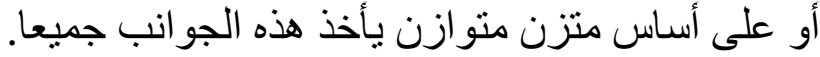

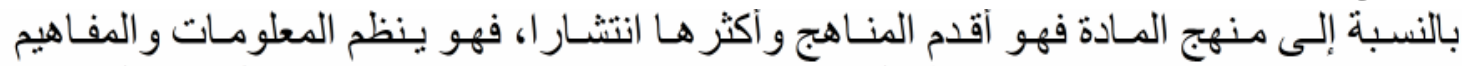

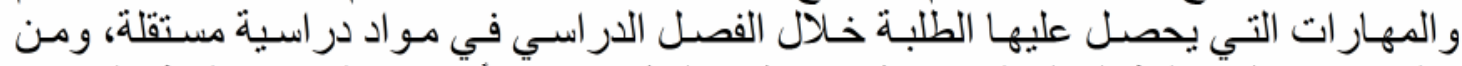

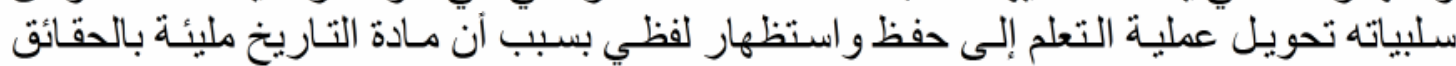
البعيدة عن خبر ات الطلبة وميولهم، إضافة إلى أن تدريس مادة تاريخ العمارة بمعزل عن غير هيل باديا 


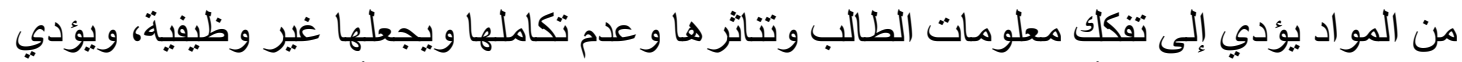

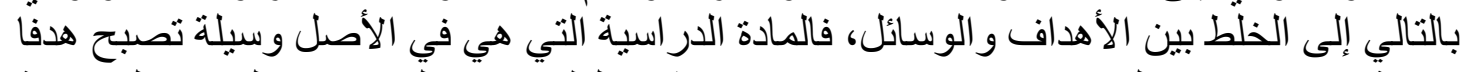

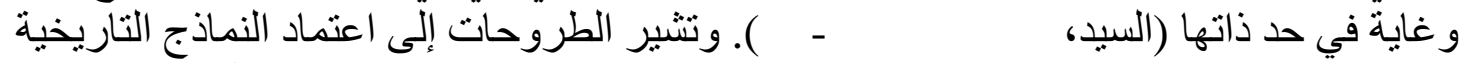

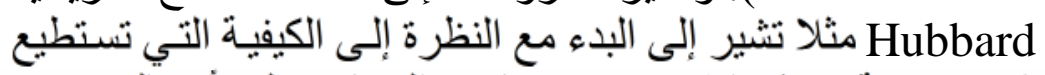

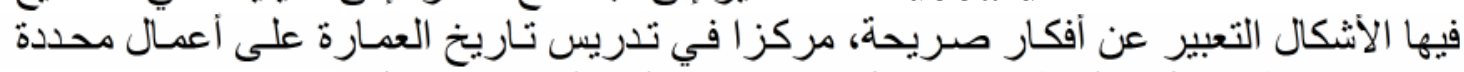

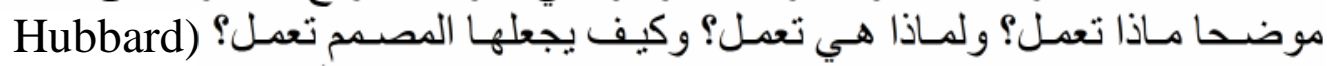
Morris

Greese) (

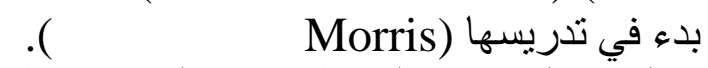

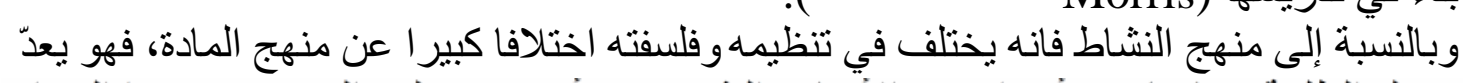

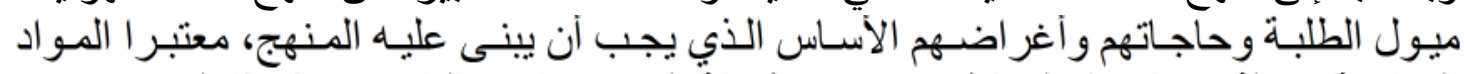

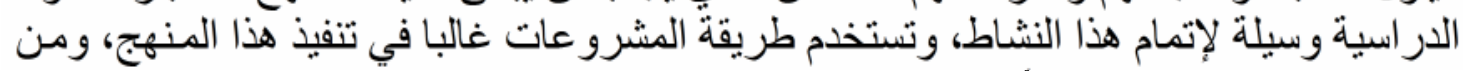

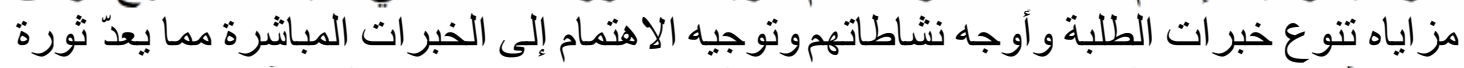

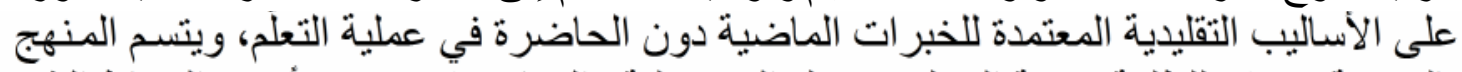

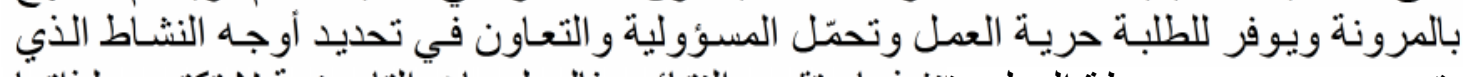

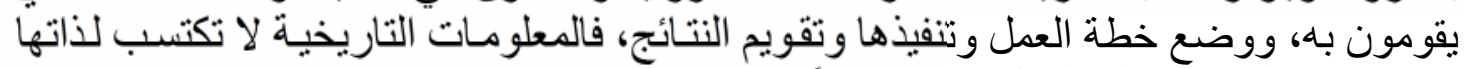

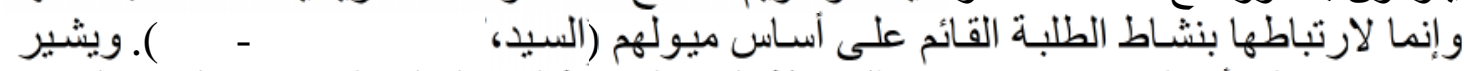

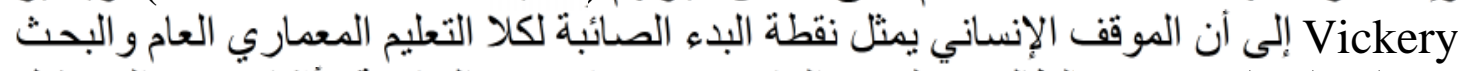

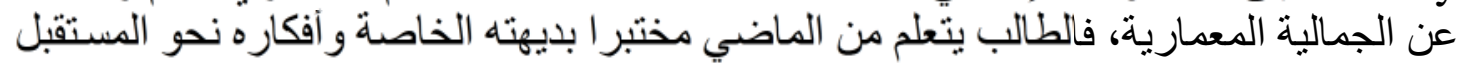

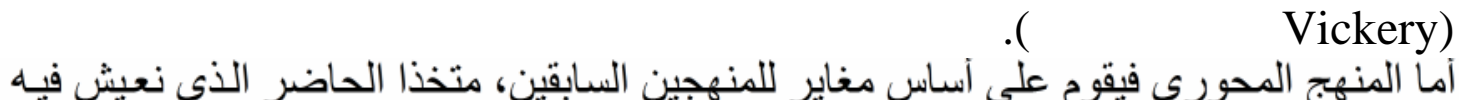

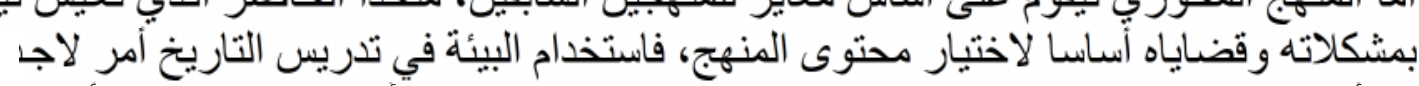

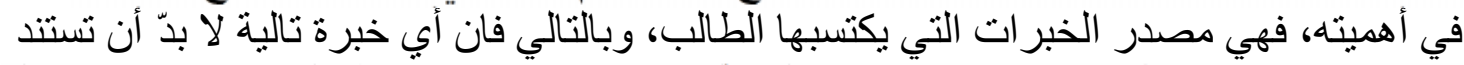

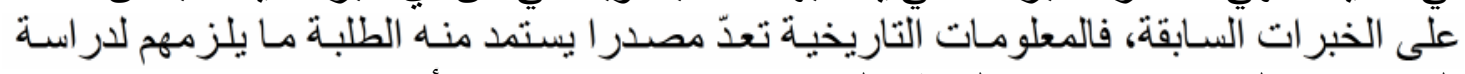

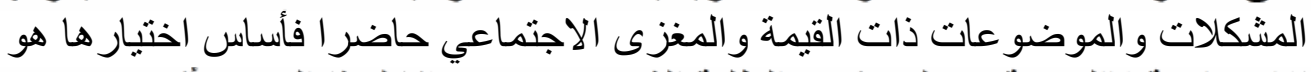

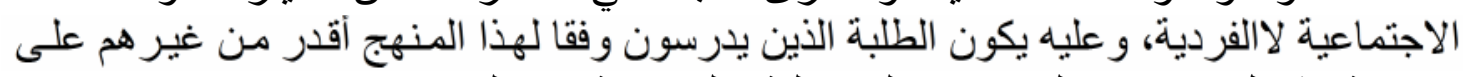

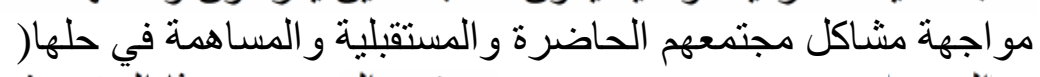

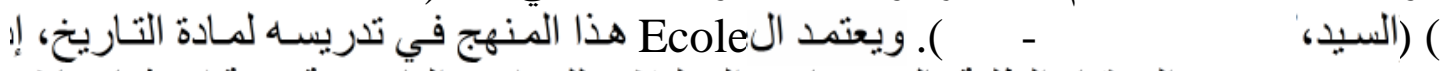

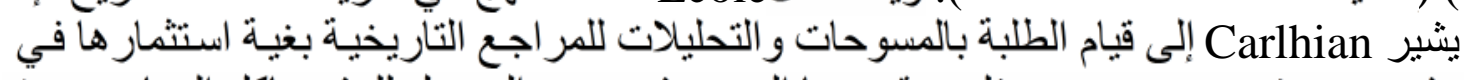

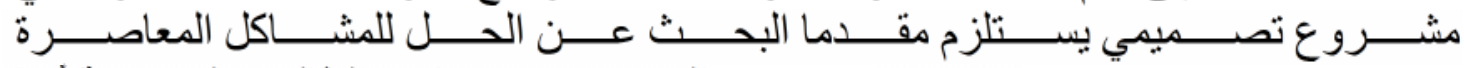

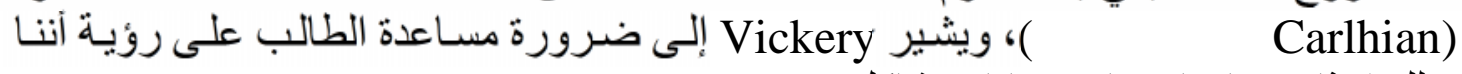

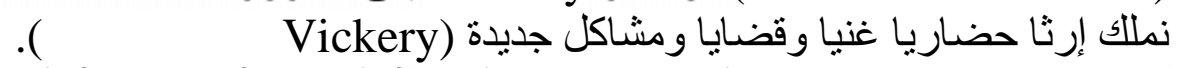

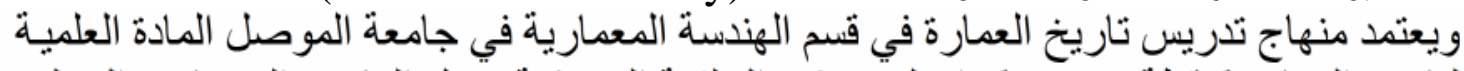

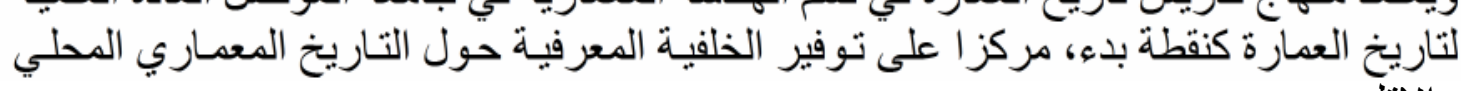

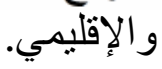

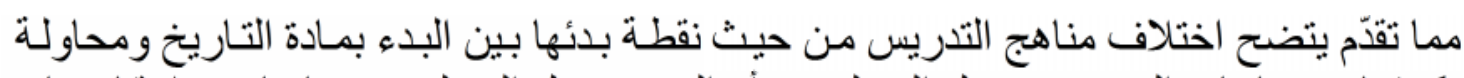

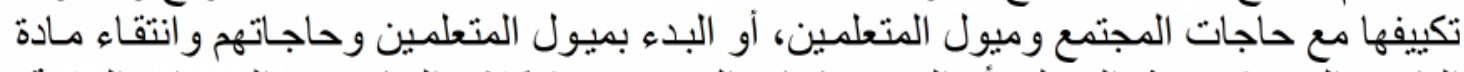

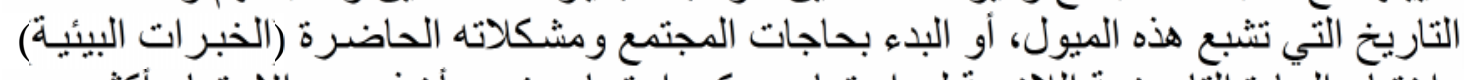

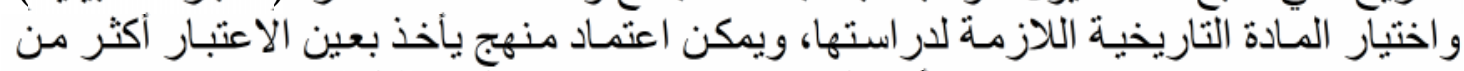

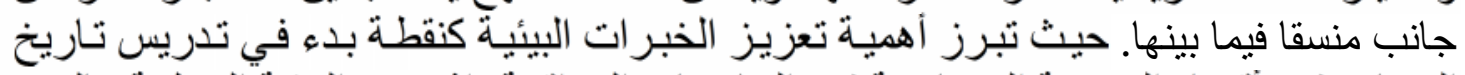

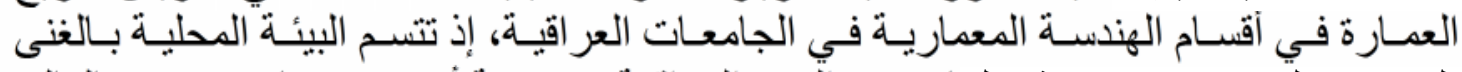

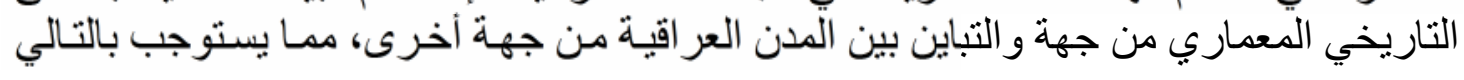




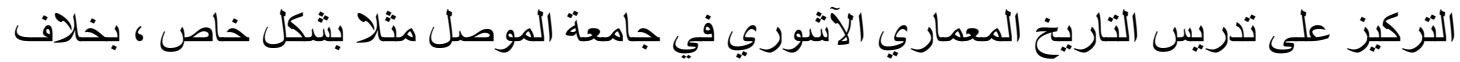
جامعة بغداد التي ينم التركيز فيها على التاريخ المعماري التئي البابلي و السومري مثنلا.

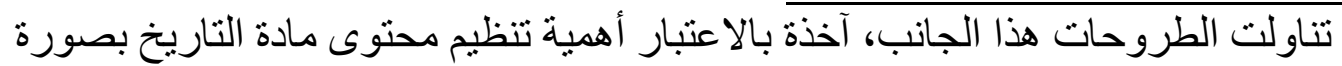

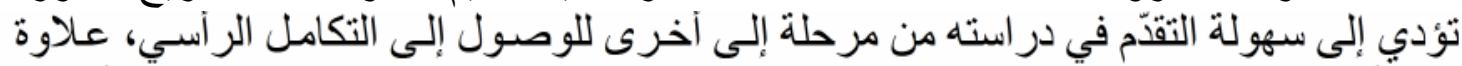

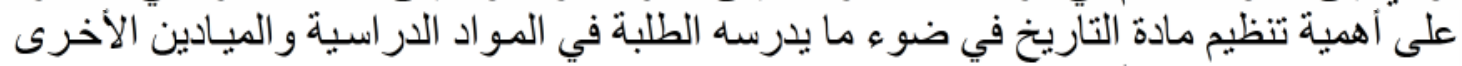

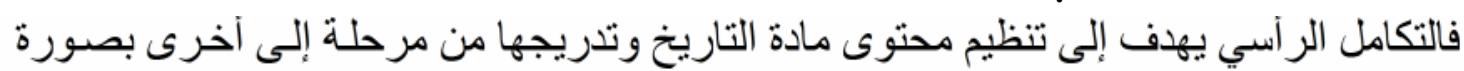

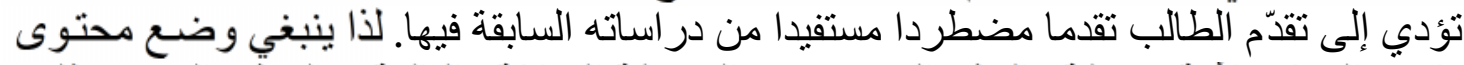

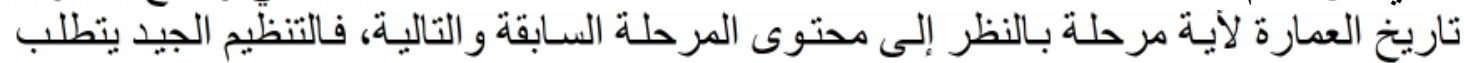

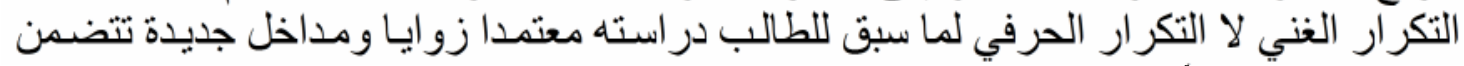
حقائق وتفسير ات أخرى للمو الخيع الكيع السابق در استها.

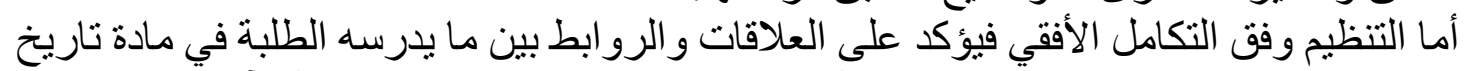

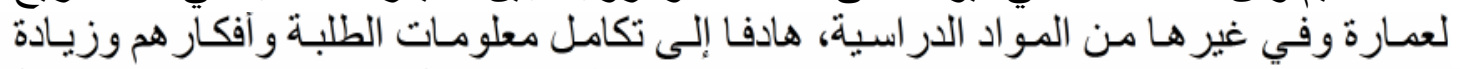

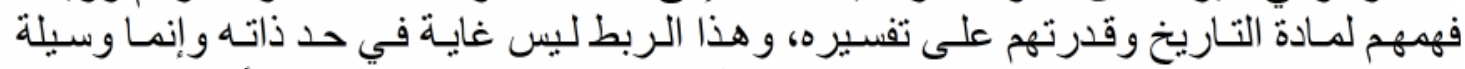

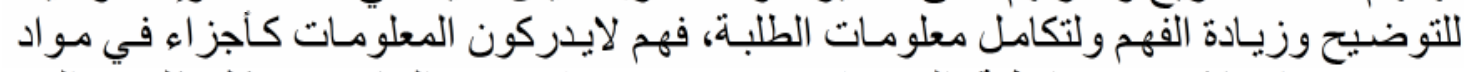

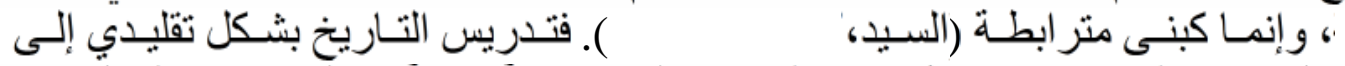

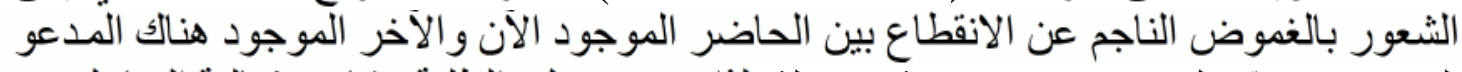

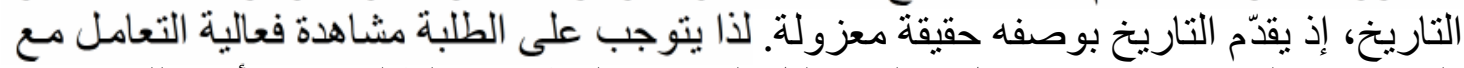

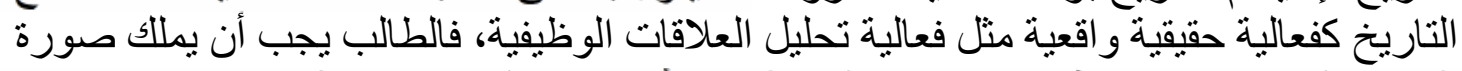

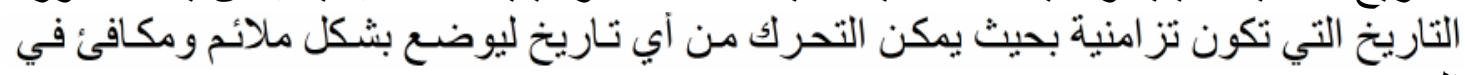

$$
\text { التصميم (Hubbard) Haryland }
$$

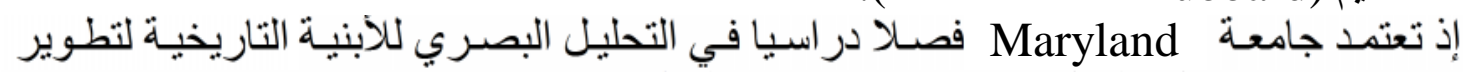

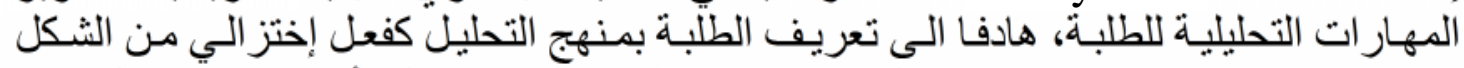

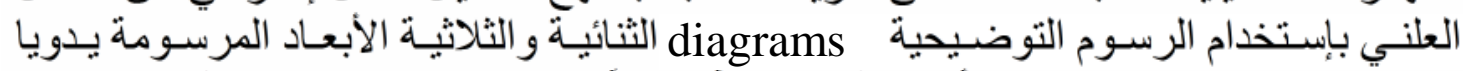

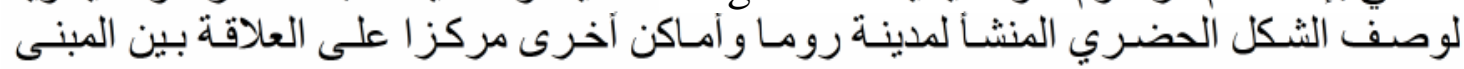

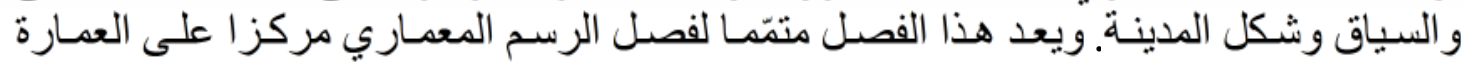

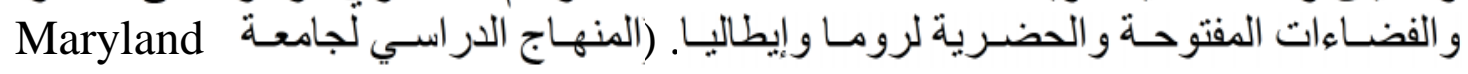

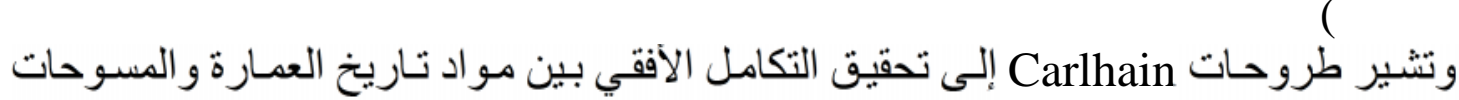

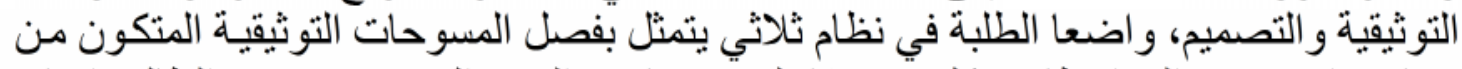

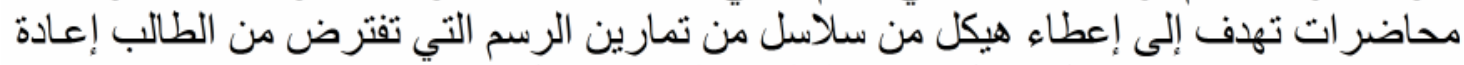

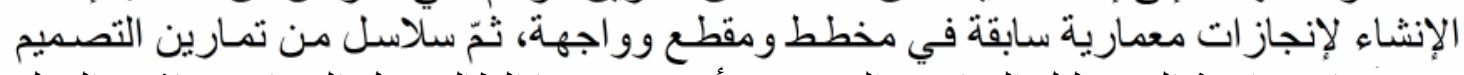

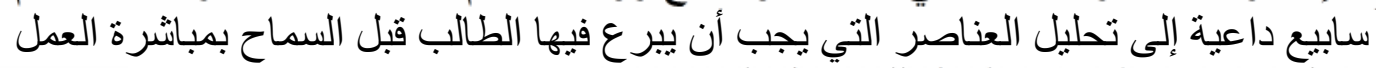

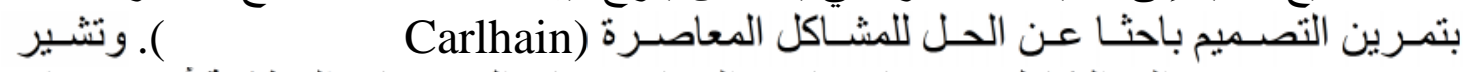
Morris

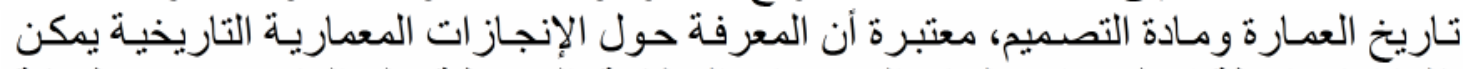

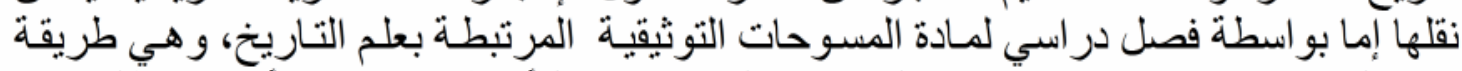

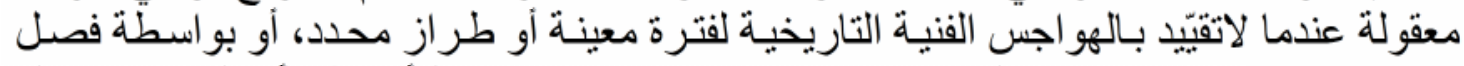

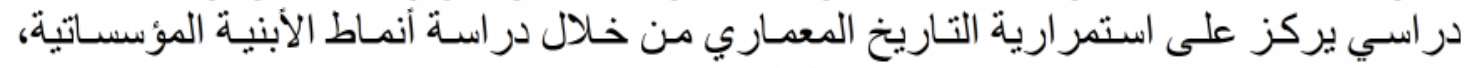

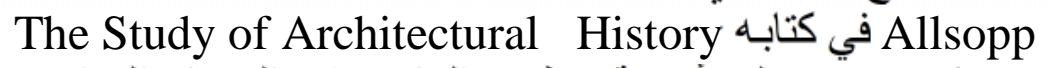
) ويؤكد Betts على أهميـة توظيف التاريخ في المنهـاج الدراسي Morris) 
المعماري، معتبر ا أنه يمثل الدليل المثنالي الموّجه للطلبة في عملهم المركز بكثافة في مر اسم

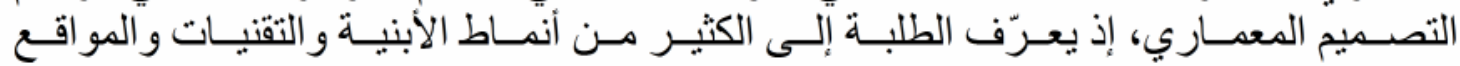

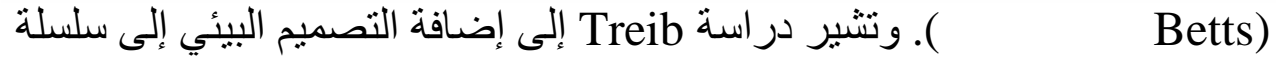

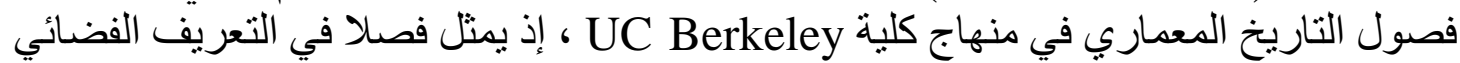

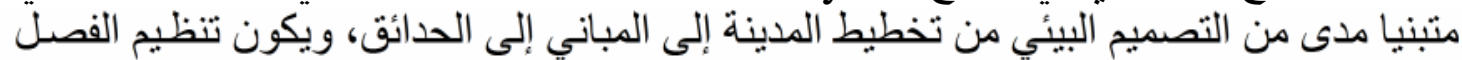

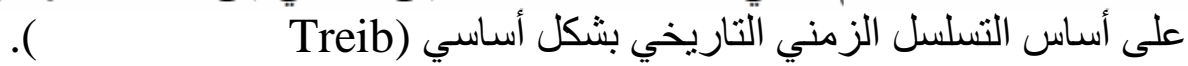

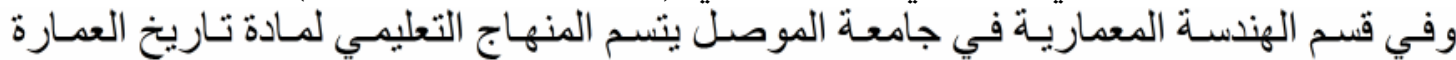

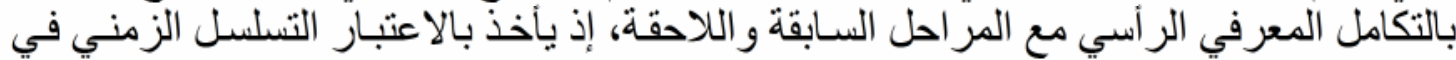

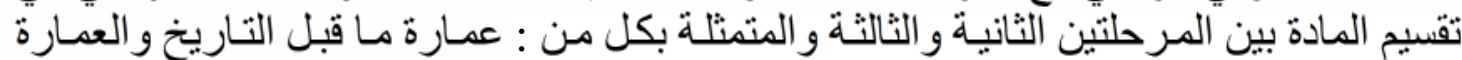

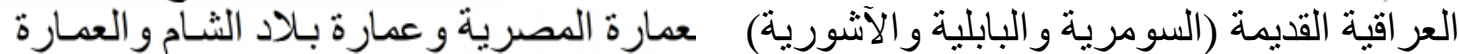

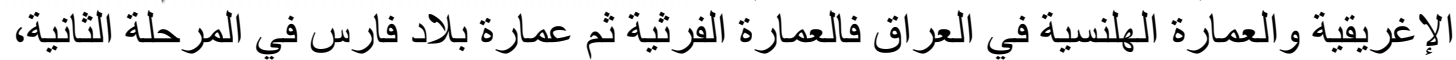

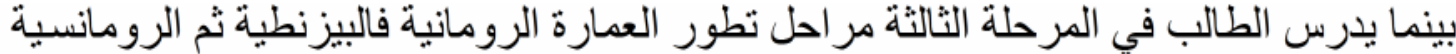

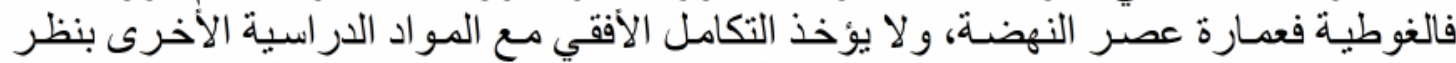

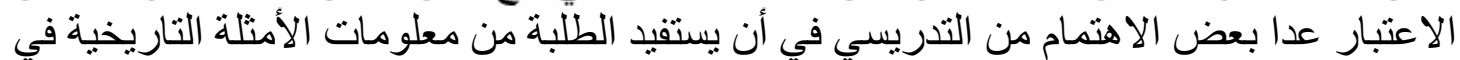

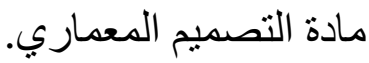

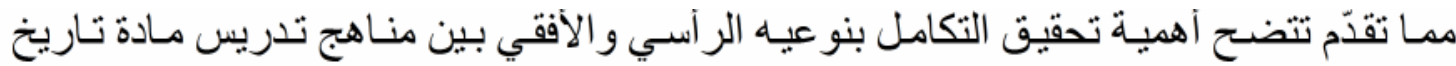

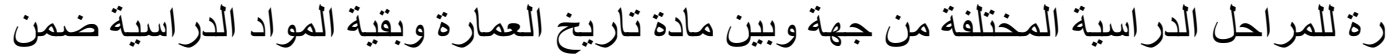

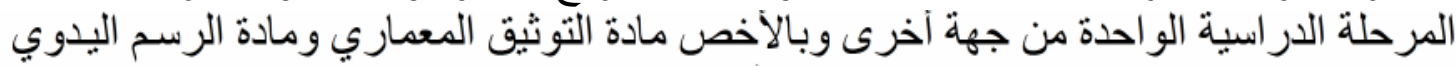

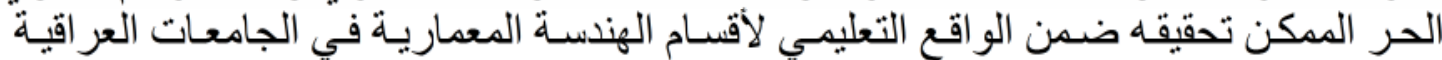

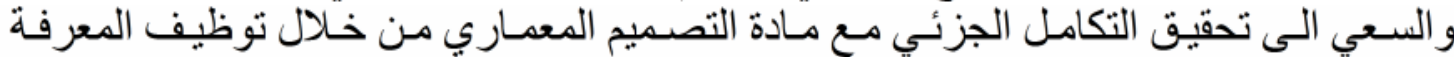
التاريخية في العملية التصميمية وضمن التئية الحدود الممكنة.

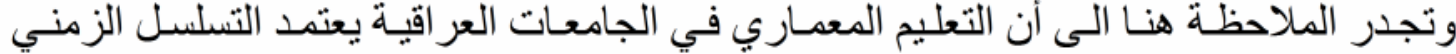

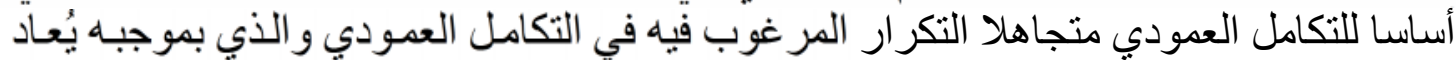

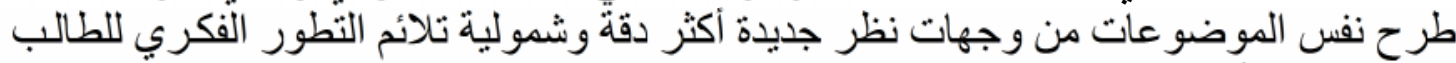

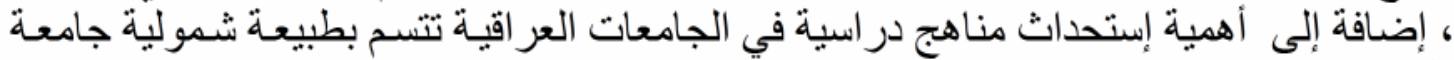

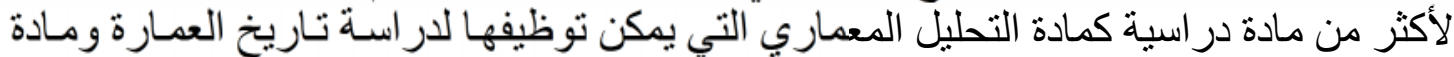

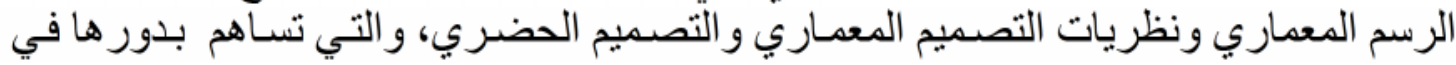
البناء المعرفي لمادة التصميم المعماري.

خامسا: مصادر المعلومات المعتمدة في العملية التعليمية

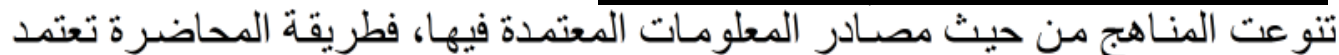

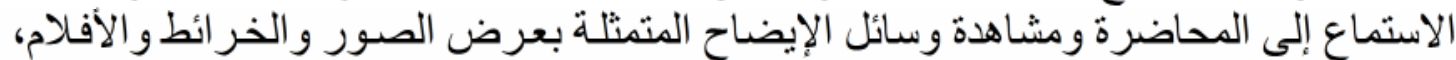

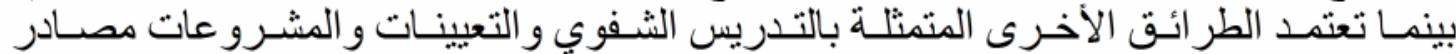

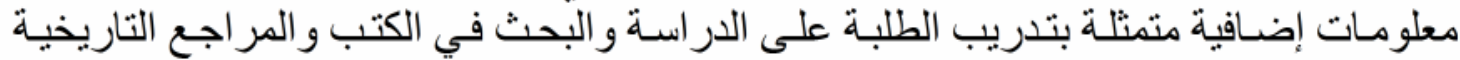

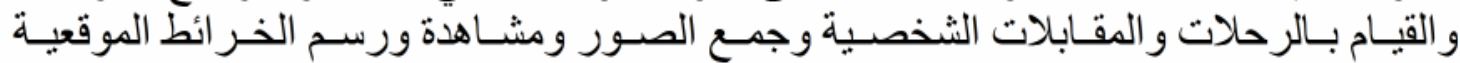

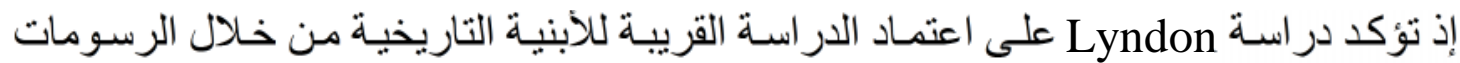

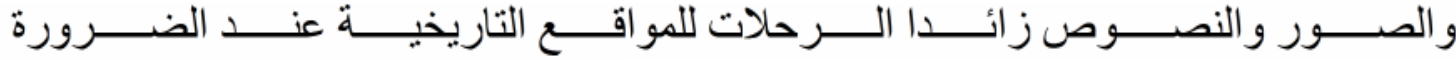

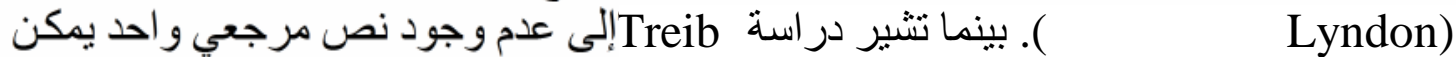

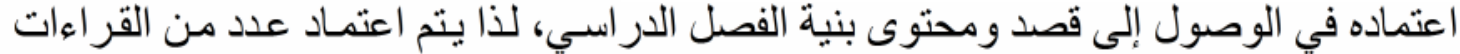

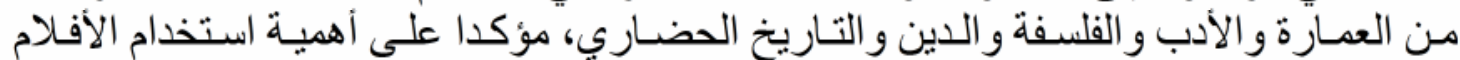

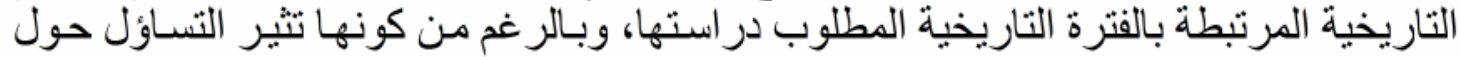




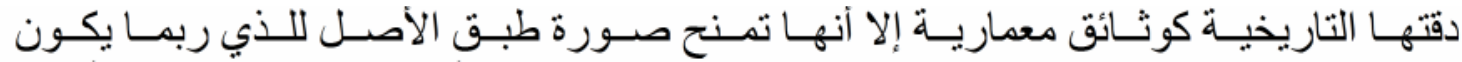
Attoe\&Moore Treib)

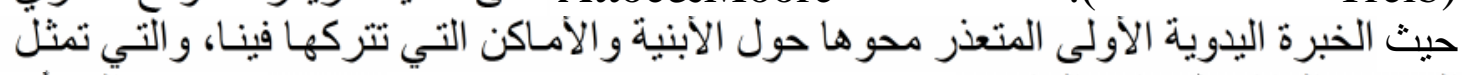

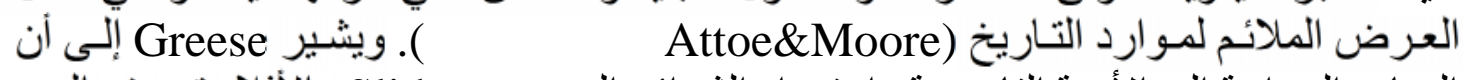

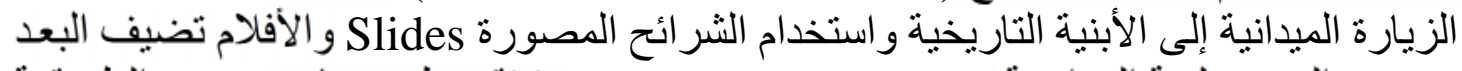

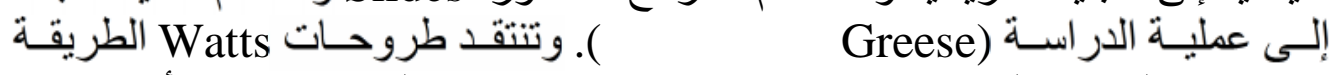

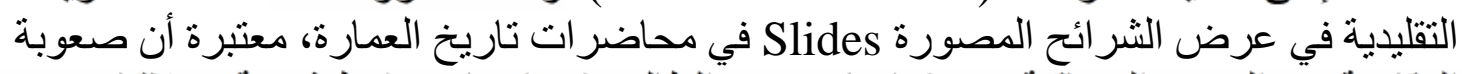

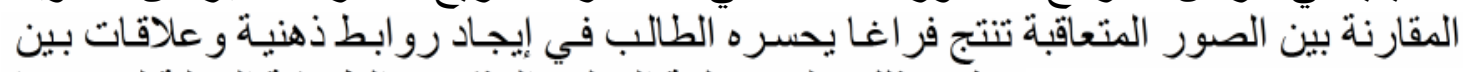

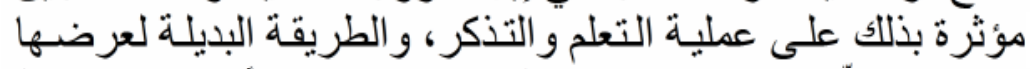

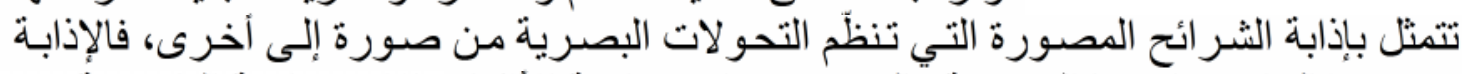

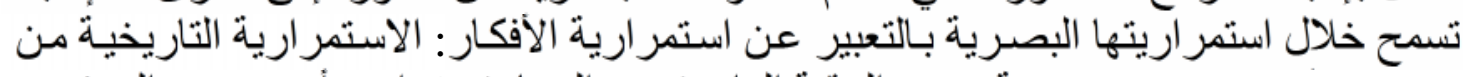

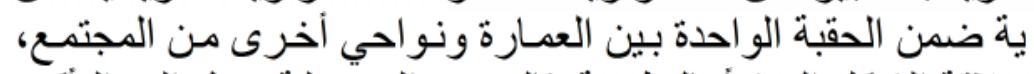

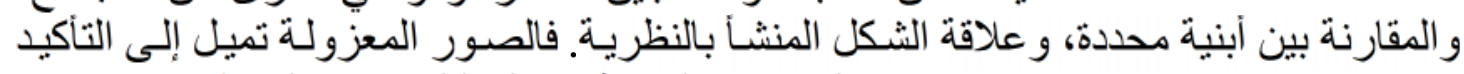

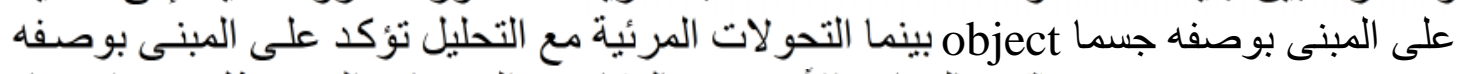

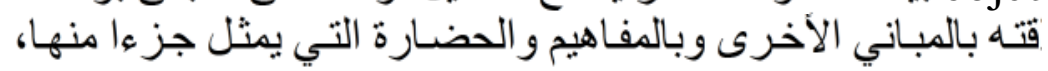

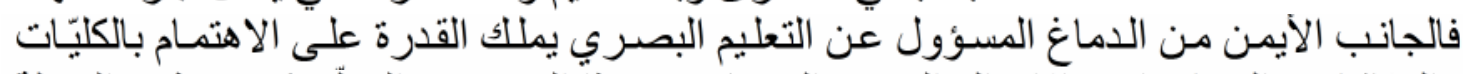

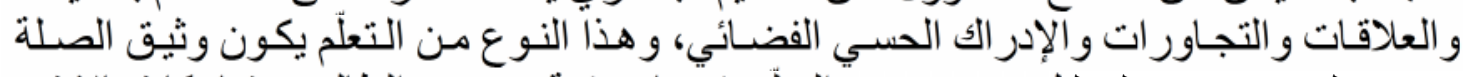

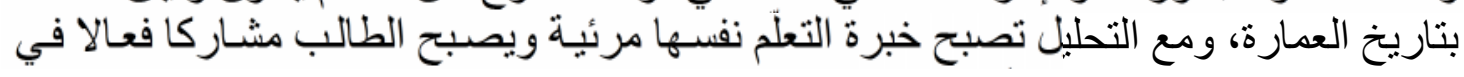

\section{( Watts)}

وتجدر الإشارة هنا إلى أن المناهج الدراسيّة في أغلب الجامعات العربية تفتقر إلى مصادر باللغنة

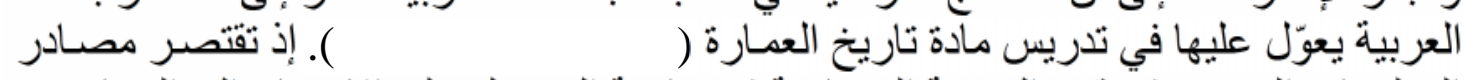
المعلومات المعتمدة في قسم الهندسة المعمارية في جامعة الموصل على الاستماع إلى المحاضرة

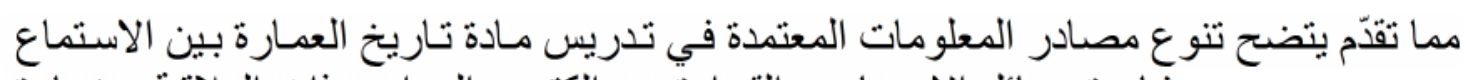

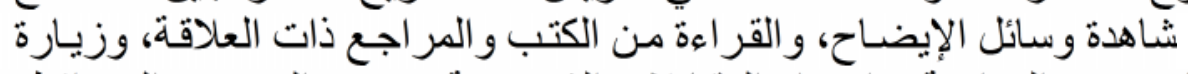

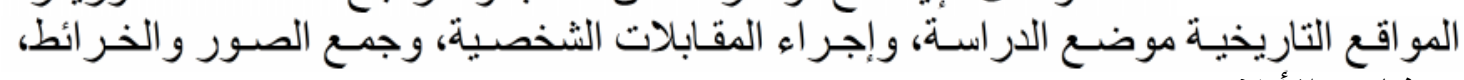

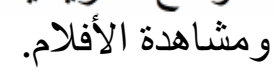

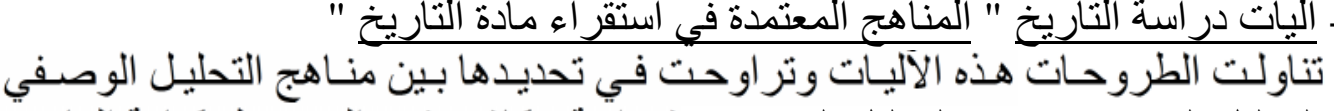

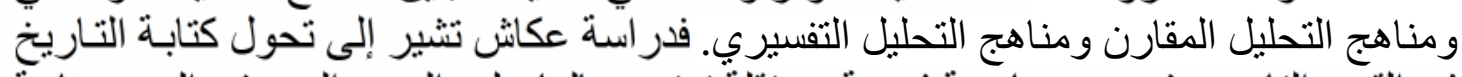

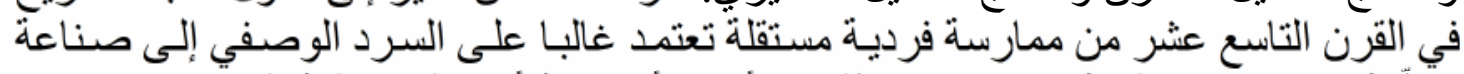

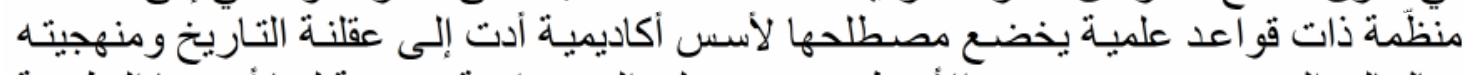

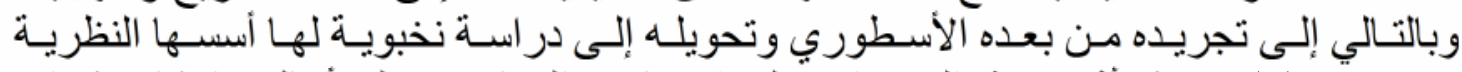

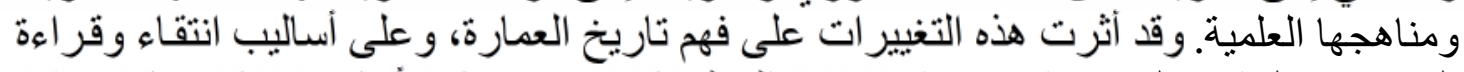

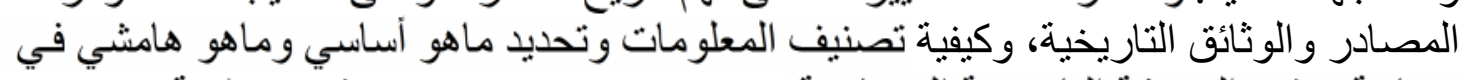

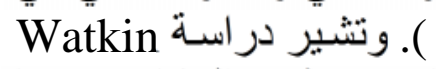

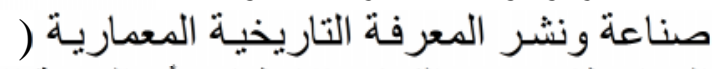

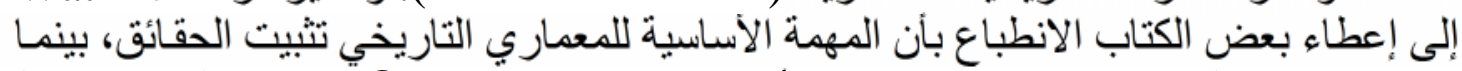

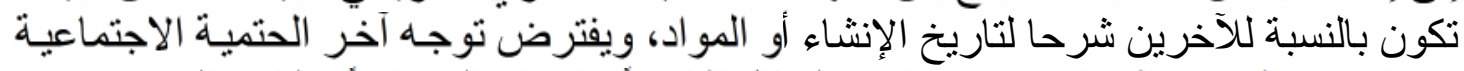

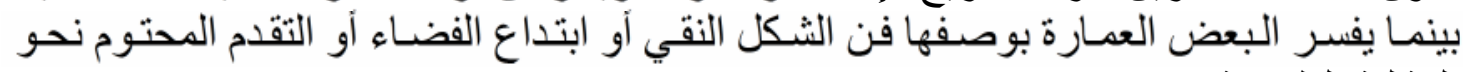


بالنسبة إلى منهج التحليل الوصفي فهو يمثل الخلاصـة الو افية للحقائق منجنبا التفسير ات، فهو

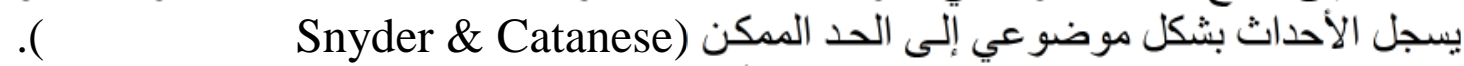

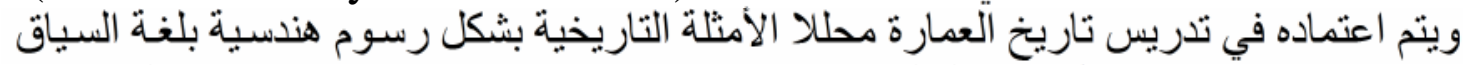

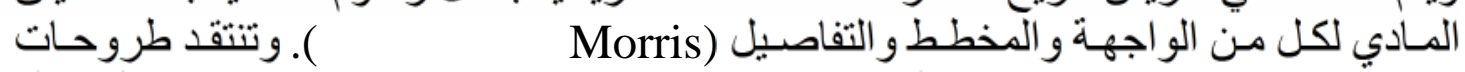

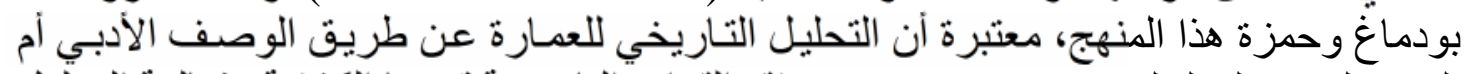

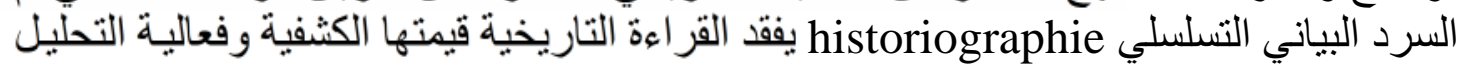

.)

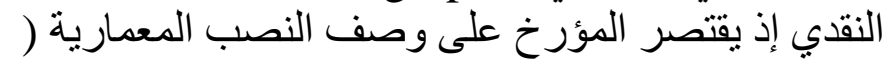

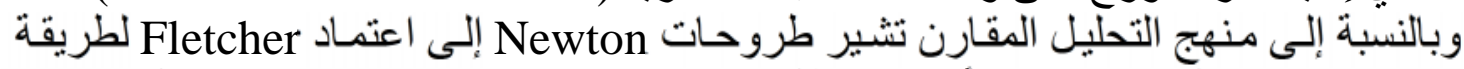

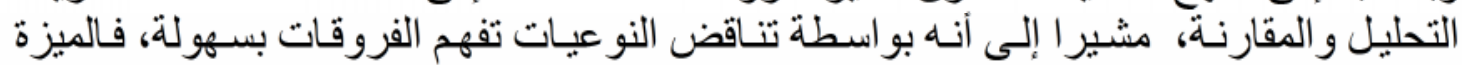

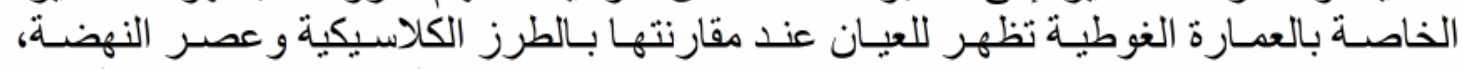

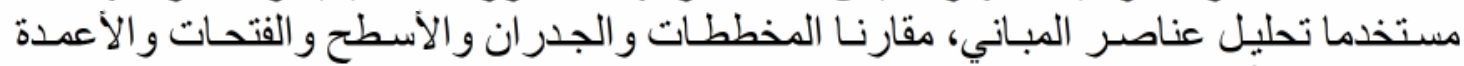

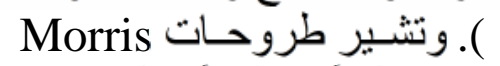

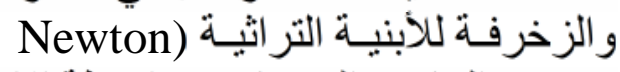

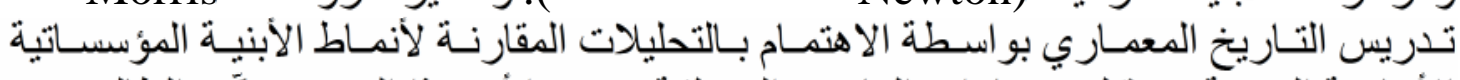

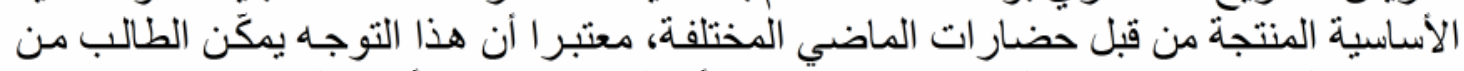

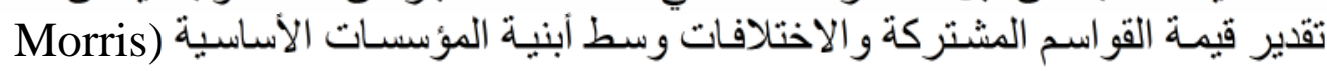

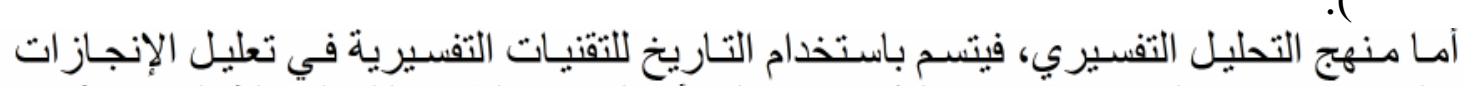

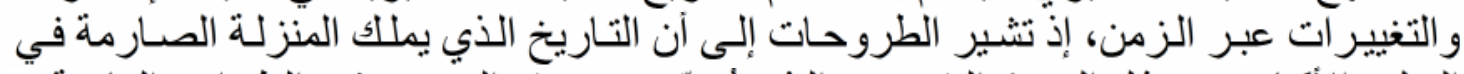

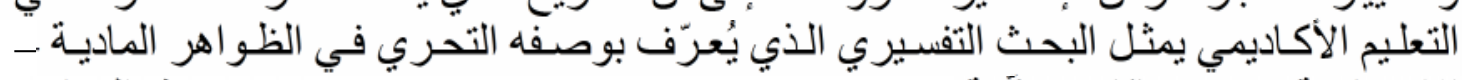

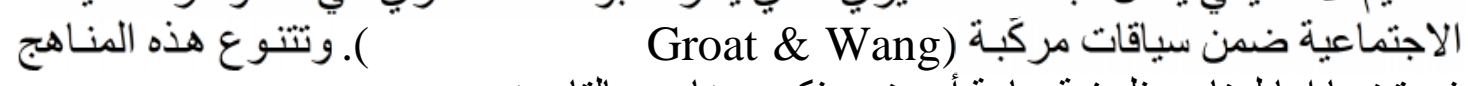

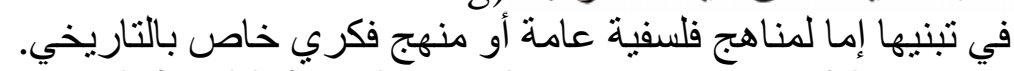

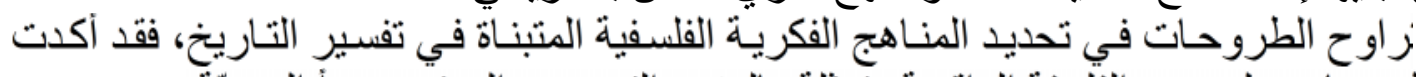

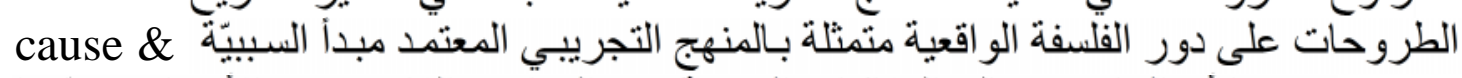

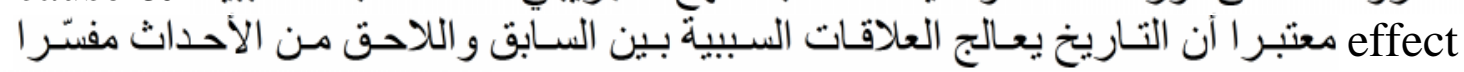

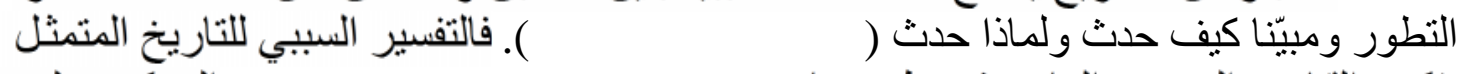

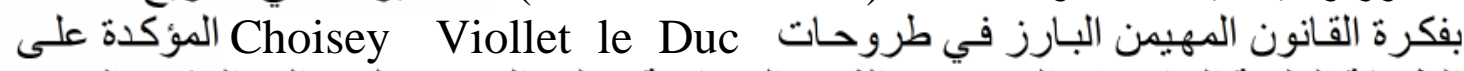

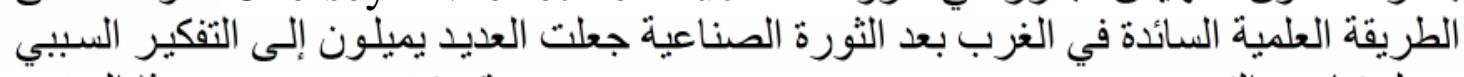

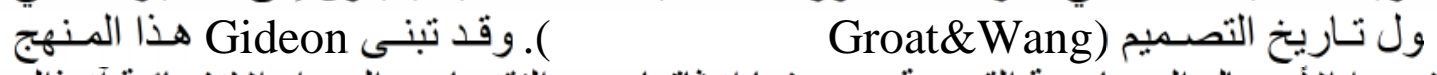

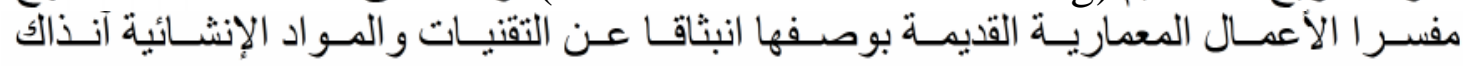
( Tzonis) وأثارت الطروحات إلى اعتماد الفلسفة العقلانية في دراسة التاريخ، فالمثالية تمثل محاولة

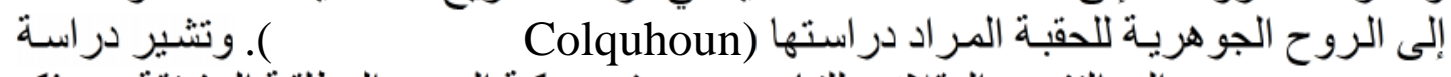
Groat \&Wang

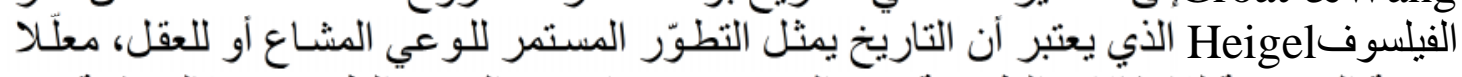

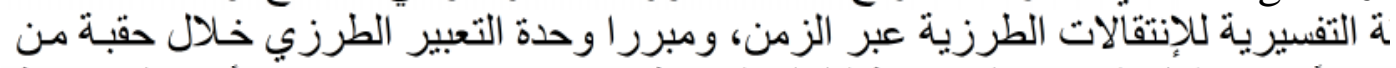

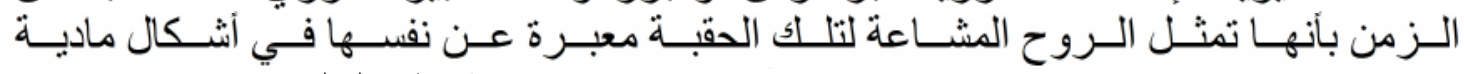

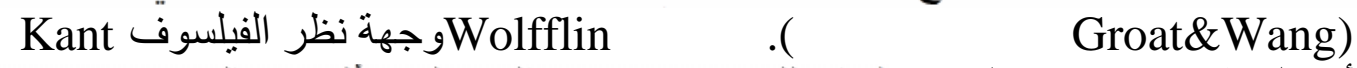

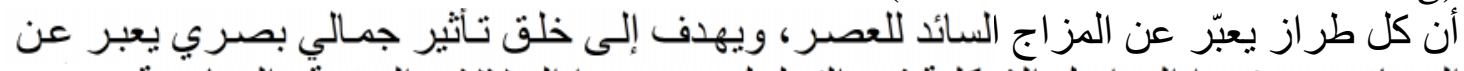

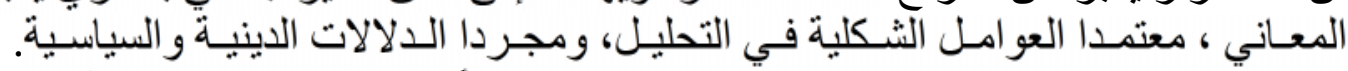
هevsner

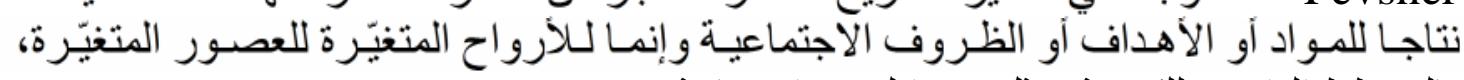

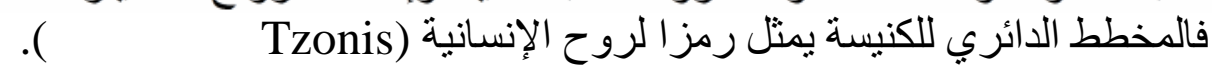




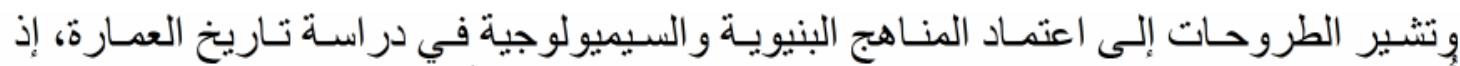

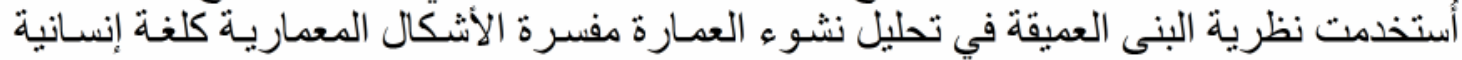

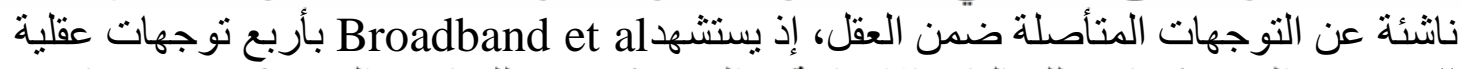

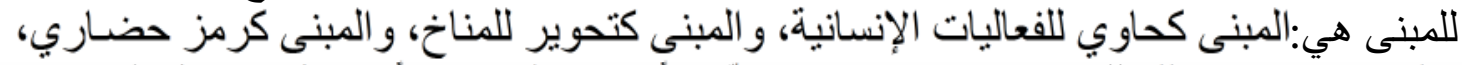

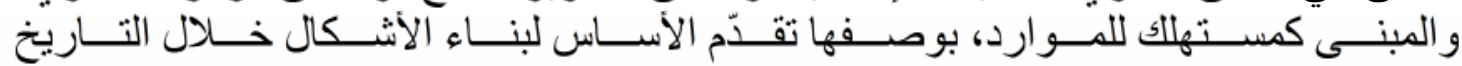

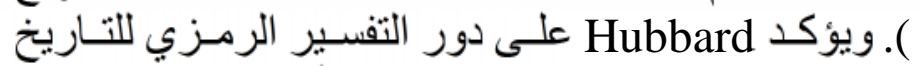

Groat\&Wang)

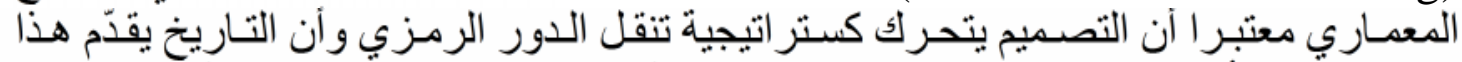

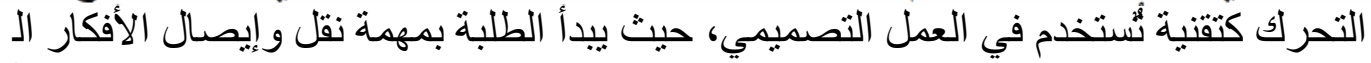

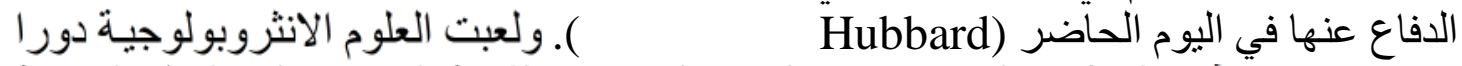

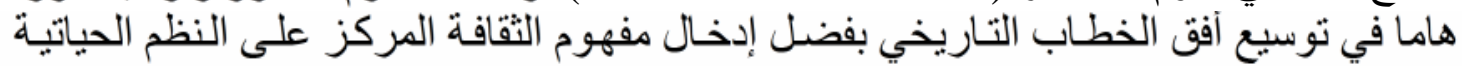

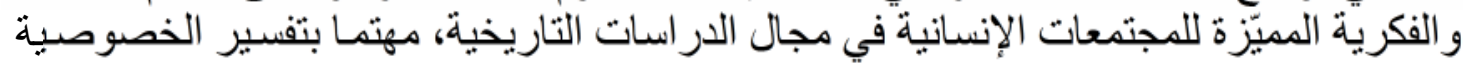

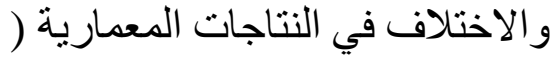

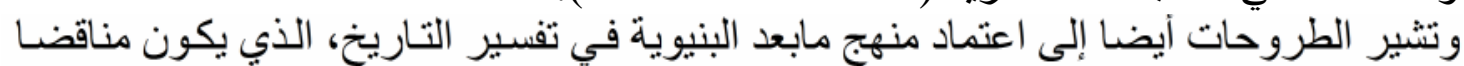

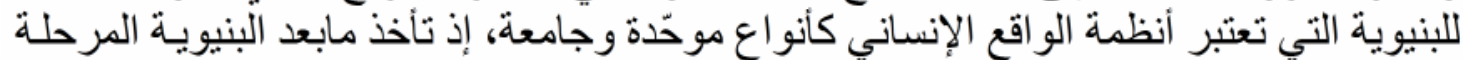

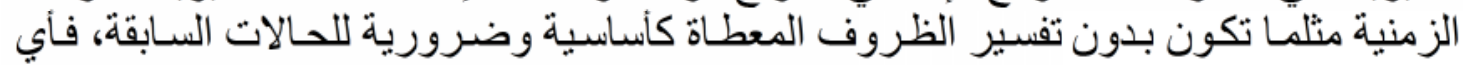

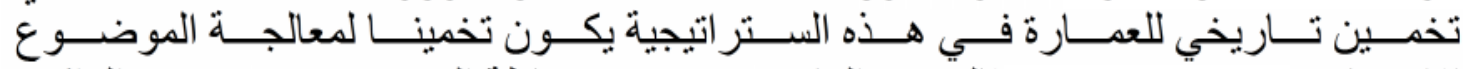

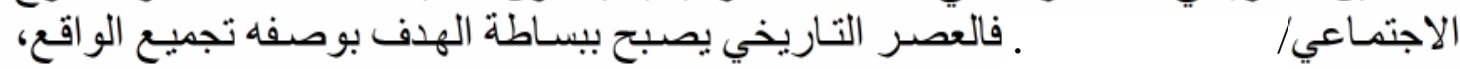

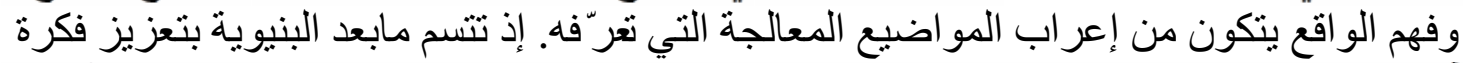

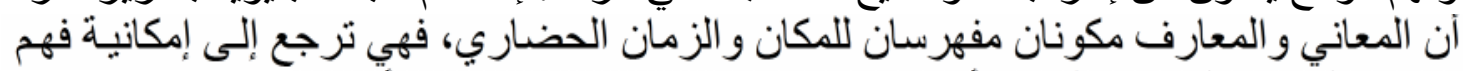

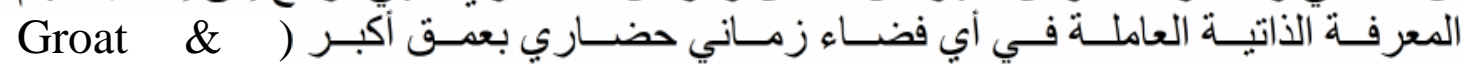
. Wang وقد يتبنى التاريخي منهجا فلسفيا خاصا باه معتمدا منهجا علميا محددا أو جامعا لاكثثر من توجـها.

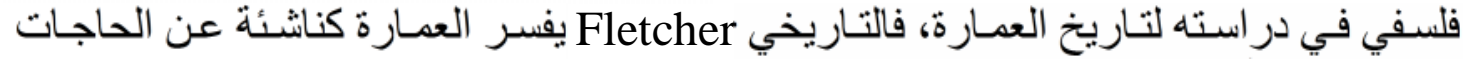

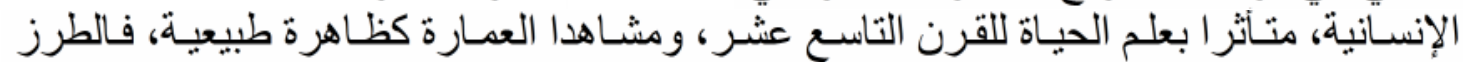

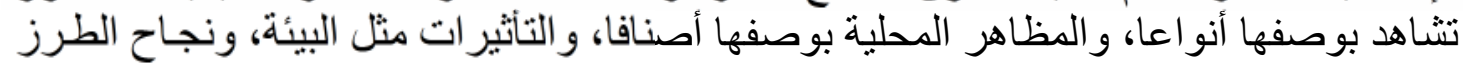
بوصفها نجاحا آو فثلا للتكييف، وقدرات التهات التكييف هذه تعتمد على العناصر التفصيلية لنتشريح Newton)

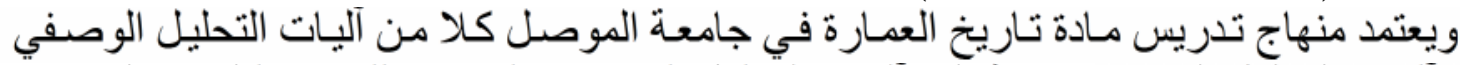

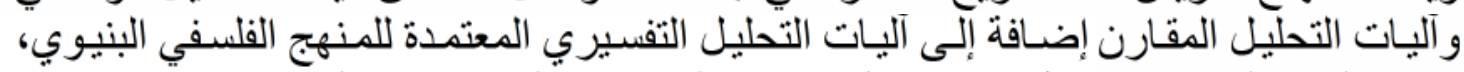

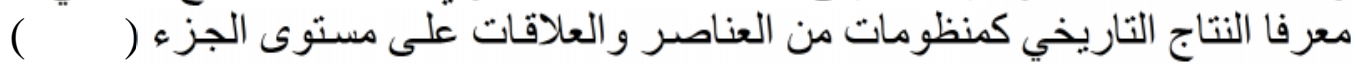

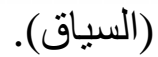

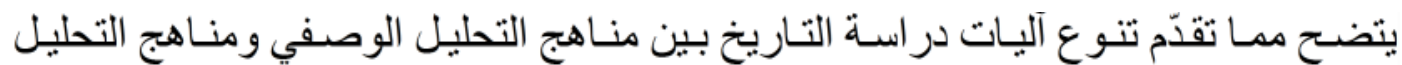

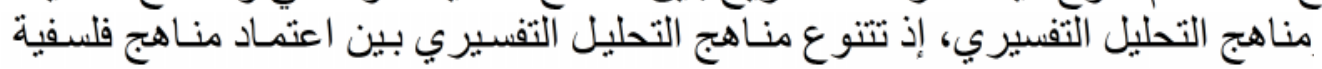

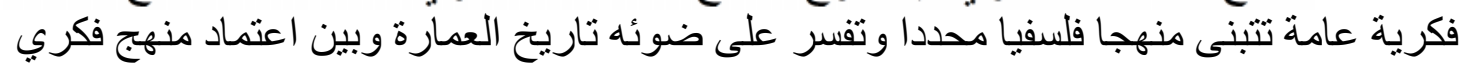

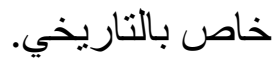

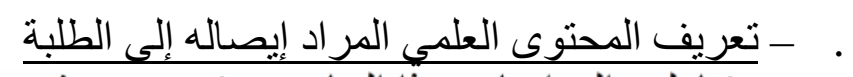

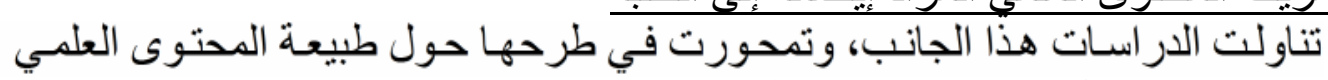

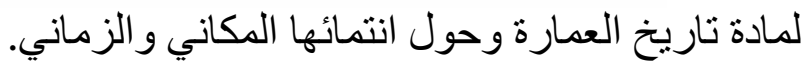

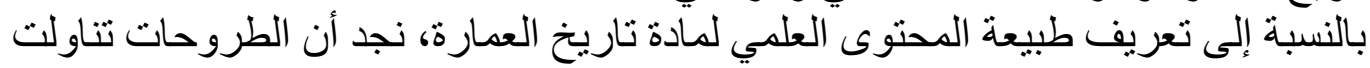

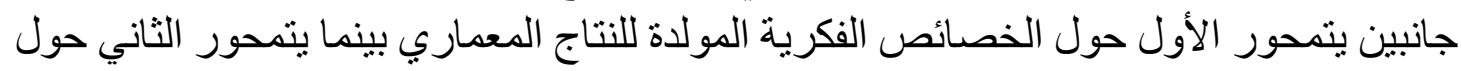

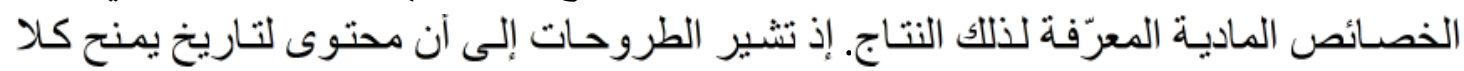




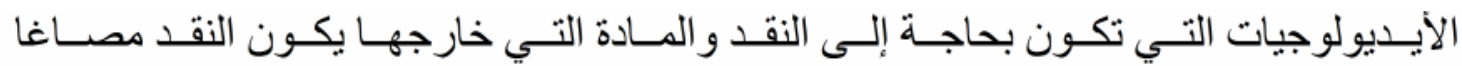
و C Colquhoun)

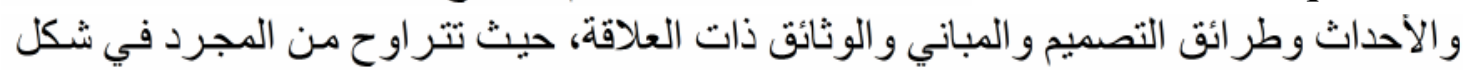

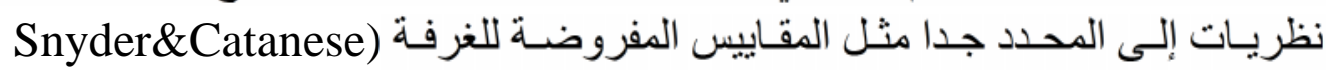

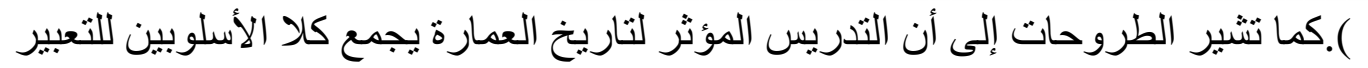

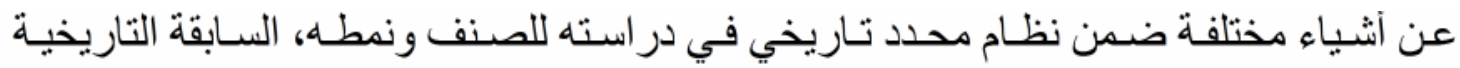

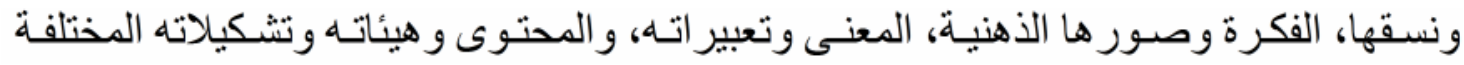
( Schneider)

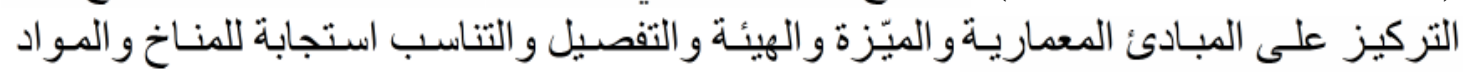
)، أو التركيز العو امل الاجتماعية

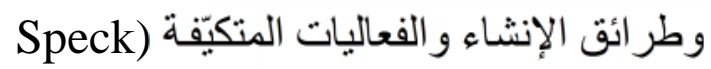

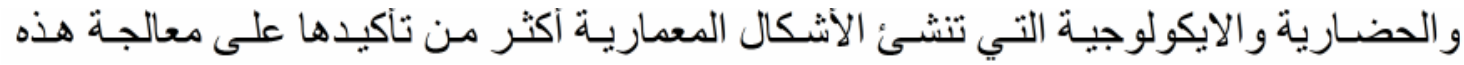

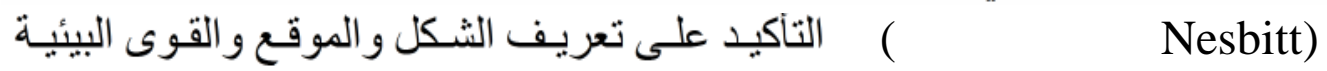

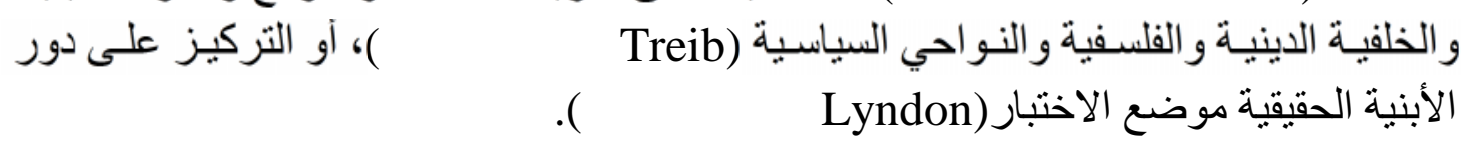

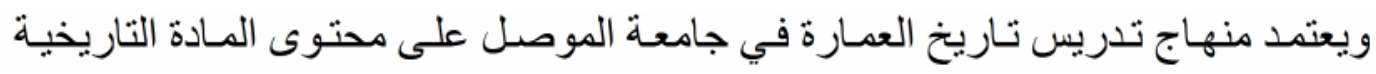

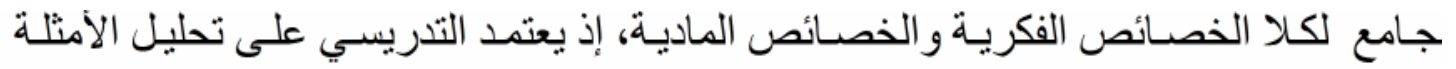

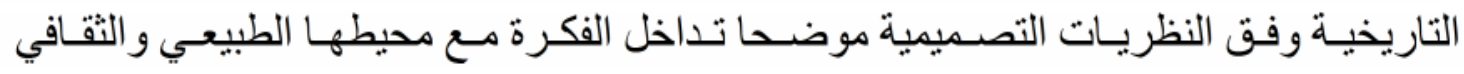
وتداخلها مع المنطلبات الوظيفية و الحلول الإنشائية و المعالجات البيئية.

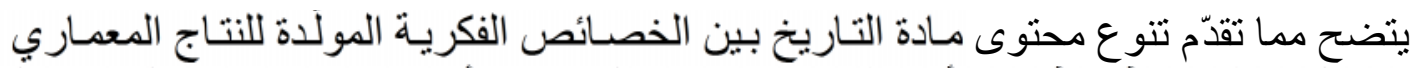

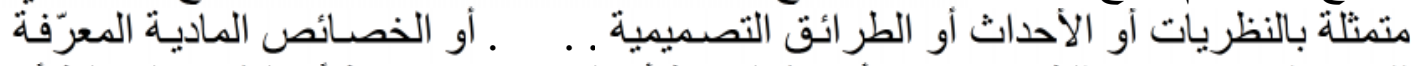

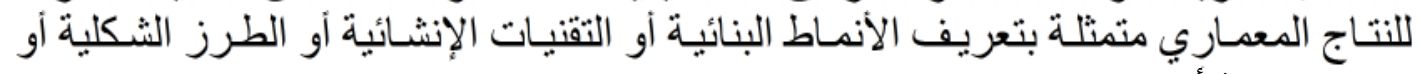
جو انب مادية أخرى المع.

وح الطروحات في تحديد كلا الانتماء المكاني و الزماني لمحتوى مادة تاريخ العمارة،

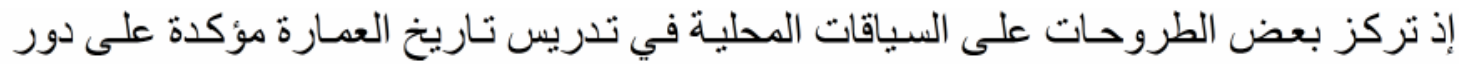

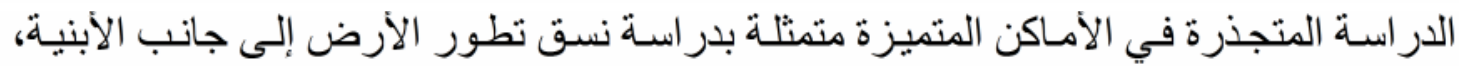

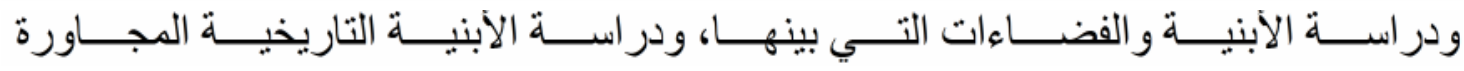

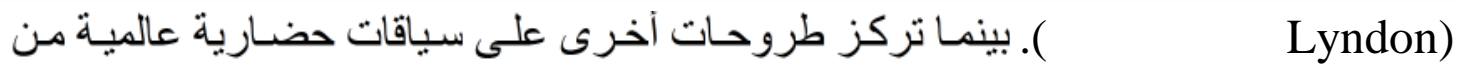

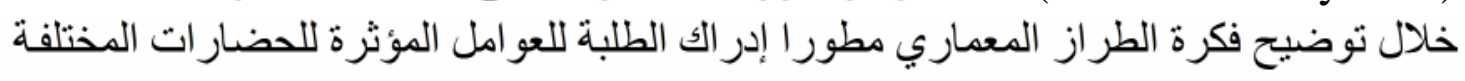
( Morris)

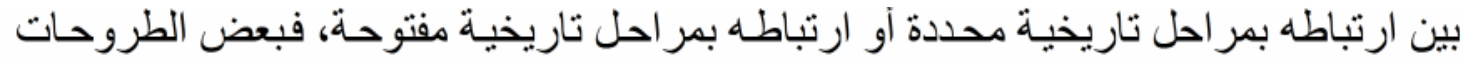

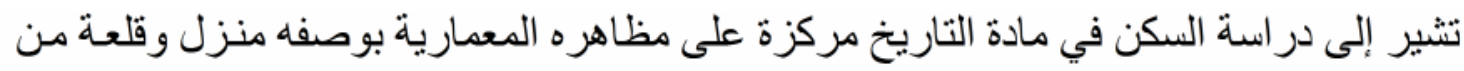

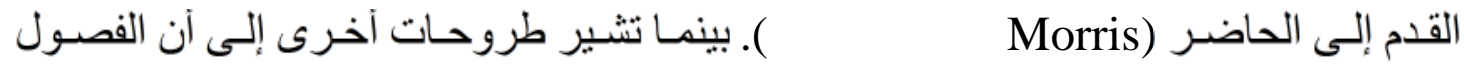

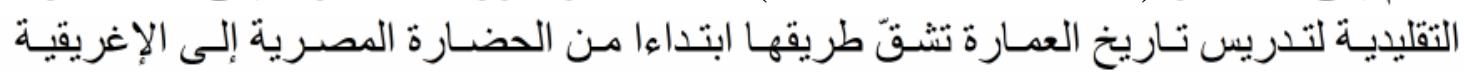

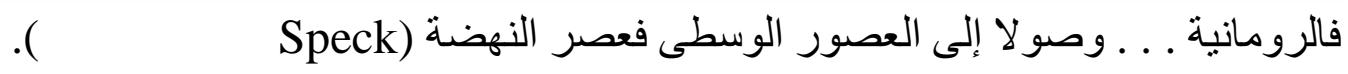
وفي منهاج تدريس تـاريخ العمارة في جامعة الموصل يرتبط محتوى النتاج التـاريخي

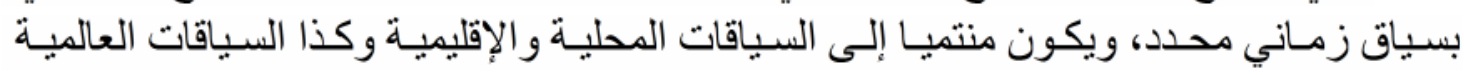


(العر اق ومصر وبلاد الثـام وبلاد فارس و اليونـان) في المرحلة الثانية بينمـا يكون منتميا إلىى السياقات العالمية (القارة الأوربية)

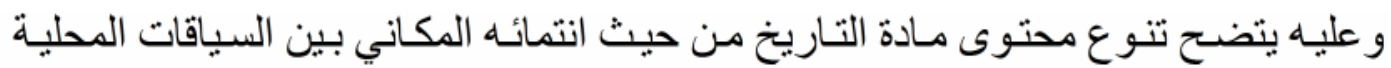
و الإقليمبة أو السياقات العالمية، و انتمائه الزماني الذي بتر بتر اوح بين ارتباطه بفترة تاريخية محددة

وجدير بالذكر أن منهاج تدريس تـاريخ العمـارة في جامعـة الموصل بركز في الانتمـاء

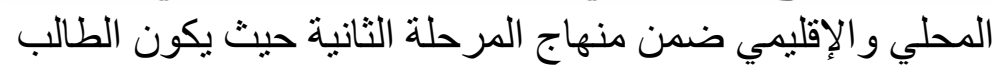

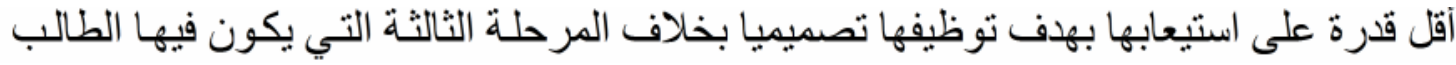

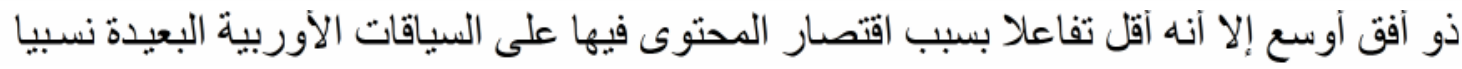
.

نشوئها وحتى الدولة الإسـامية مثثلا و الذي على إدر الك الطالب لمفاهيم الاستمر ارية و التطور

بنـاءا على مـا تقدم توصل البحث إلى بلورة أبرز الجوانب التي تعرف كل من أهداف تدريس مادة تاريخ العمارة و الوسائل المستخدمة في تحقيقها.

تتمحور استنتاجات البحث حول تعريف كل من الأهداف و الوسائل الممكن إعتمادهـا في التدريس الفاعل لمادة تاريخ العمارة وكما يلي :

•تتمحور أهداف تدريس مادة تاريخ العمارة حول أهداف مباشرة تهتم بتتمية التفكير

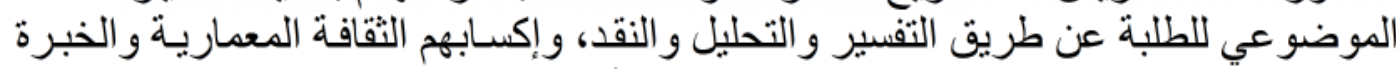

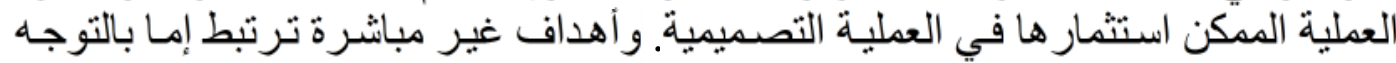

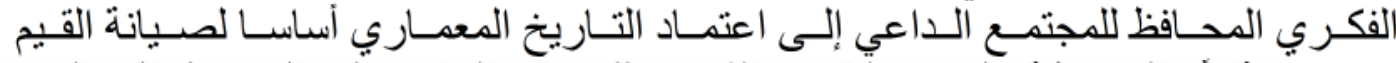

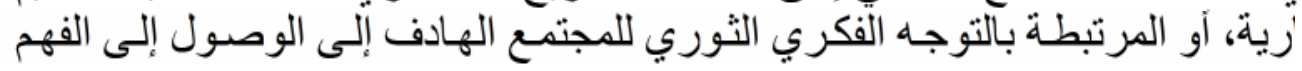

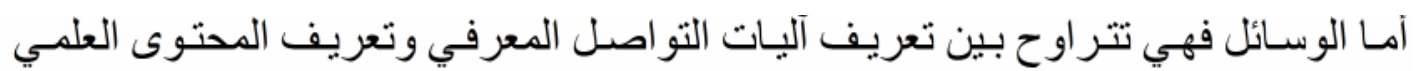

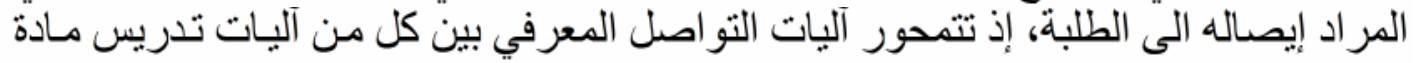

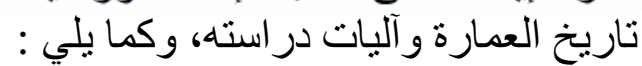

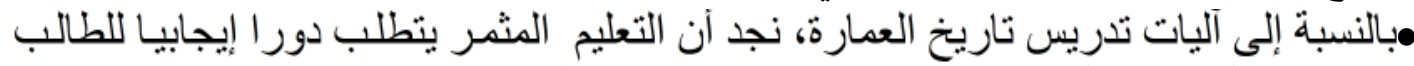

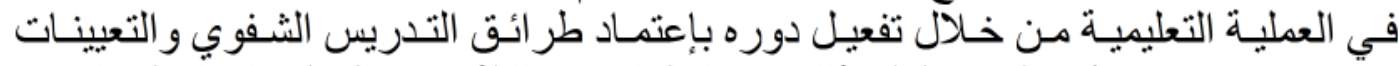

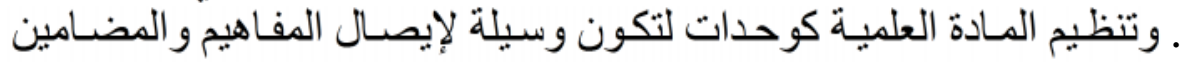


الممكن توظيفها عمليا. و إعتماد مادة التاريخ إضافة الى الخبرات البيئية وميول الطلبة كنقطة

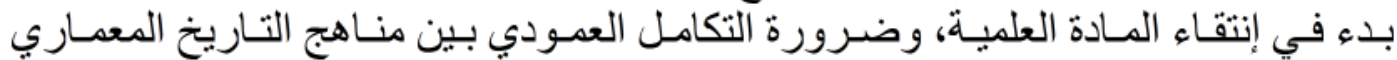

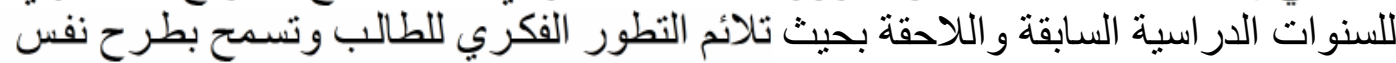

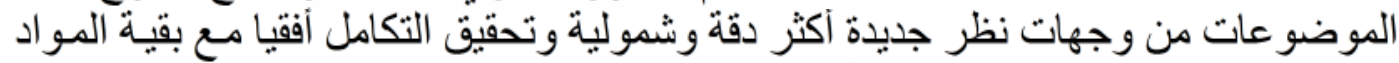

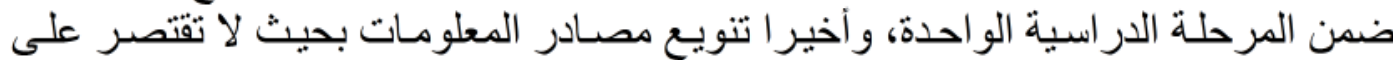

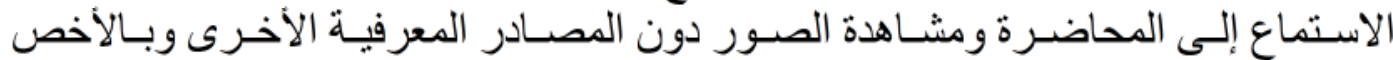

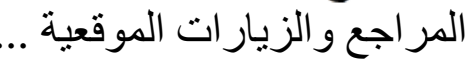

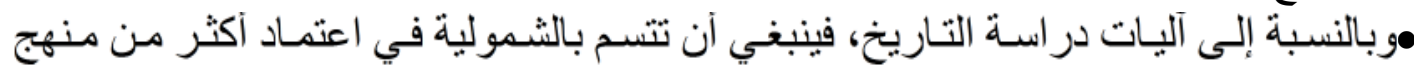
كالمنهج الوصفي ومنهج التحليل المقارن ومنهج التحليل التفسيري المعتمد للفلسفة البنيوية في

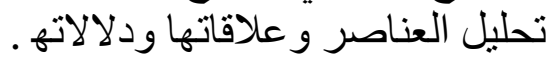

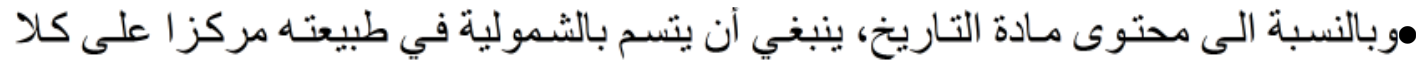

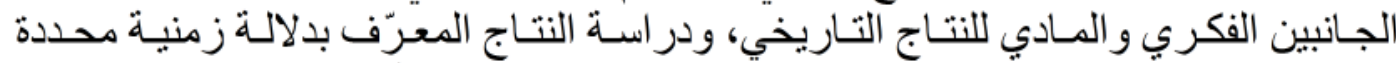

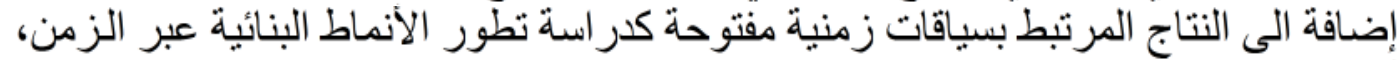

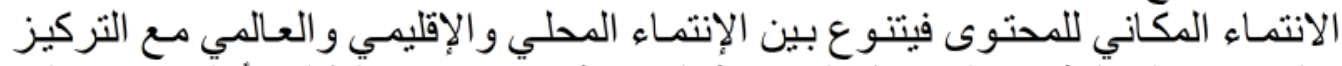

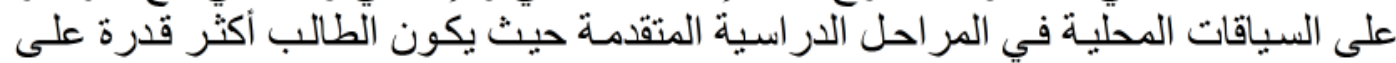
التفاعل معها لإستثمار ها تصميميا.

•ـ التوصيات

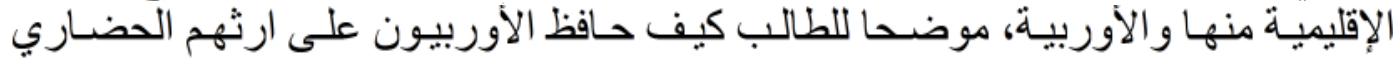
للوصول إلى السبل الكفيلة بالحفاظ على الإنى ارثنا الحضاري.

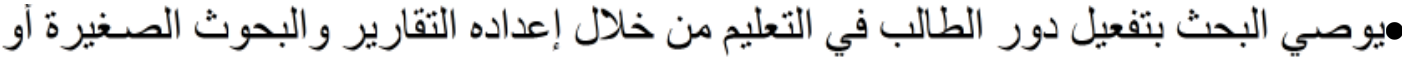

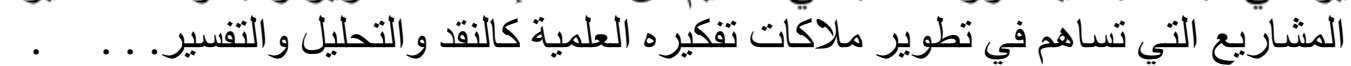

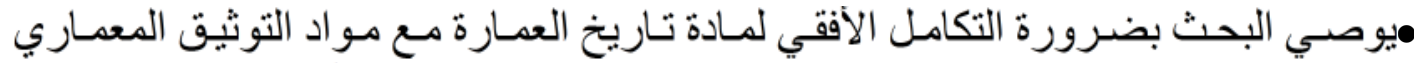

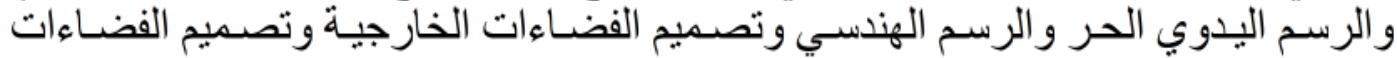

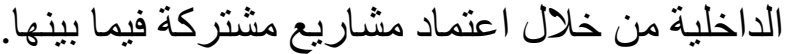

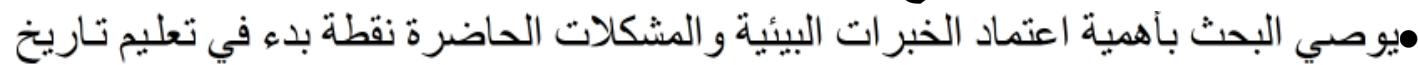

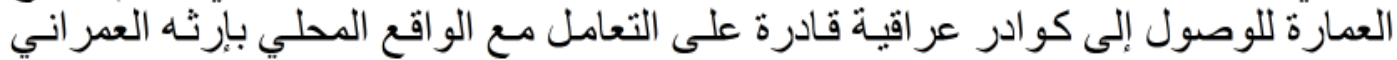

• المصادرِ عبد الحمبد، "التـاريخ في التعليم الثانوي"، مكتبـة الأنجلو المصـرية، القـاهرة، • اللقـائي، أحمـد حسـين، "اتجاهـات في تـدريس التـاريخ"، عـالم الكتب للنشـر، القـاهرة،

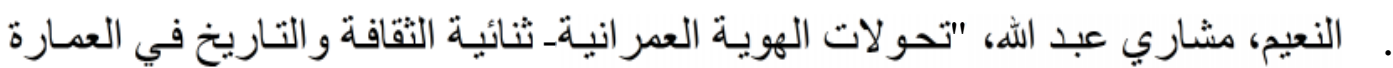

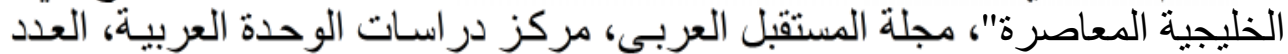

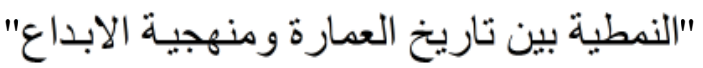
بيروت،

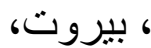
مجلة المستقبل العربي، مركز در اسات الوحدة العربية، العدد

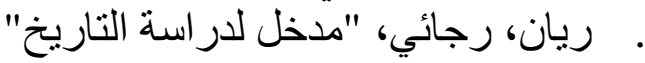




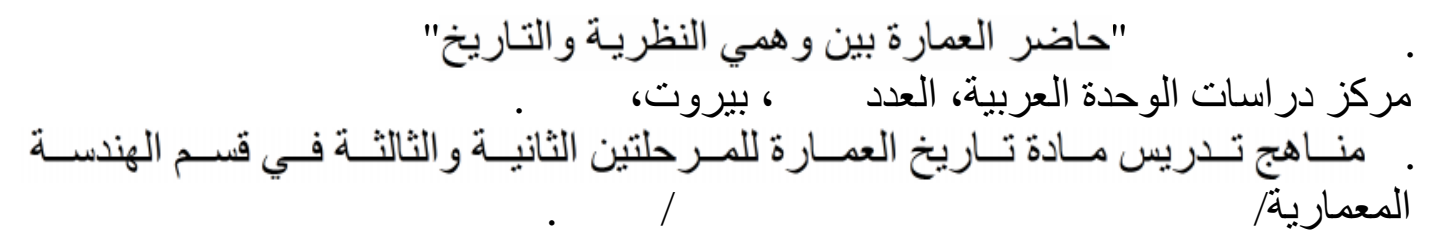

8. Anderson, Robert L, "How Not To Teach Architectural History", Journal of Architectural Education, Vol.XXX1V, N.1, 1980.

9. Arnaud, Leopold, "How Not To Teach Architectural History", Journal of Architectural Education, Vol.XXX1V, N.1, 1980.

10.Attoe \& Moore, Wayne \& Charles, "On Mining History", Journal of Architectural Education, Vol.XXX1V, N.1, 1980.

11.Bannister, Turpin, , "How Not To Teach Architectural History", Journal of Architectural Education, Vol.XXX1V, N.1, 1980.

12.Betts, Richard, "Historical Determinism Or Historical Precedent Be Demand", Journal of Architectural Education, Vol.XXX1V, N.1, 1980.

13.Carlhian, Jean Paul, "History at the Ecole", Journal of Architectural Education, Vol.XXX1V, N.1, 1980.

14.Colquhoun, Alan, "Theorizing a New Agenda For Architecture", Princeton Architectural Press, New York, 1996.

15.Greese, Walter, "Reflections On How To/ How Not To Teach Architectural History", Journal of Architectural Education, Vol.XXX1V, N.1, 1980.

16. Grroat \& Wang, Linda \& David, "Architectural Research Method", John Wiley \& Sons, INC, USA, 2002.

17.Hubbard, Bell, "Theory For Practice", MIT Press, USA, 1996.

18.Hubbard, William Q, "History Synchrony", Journal of Architectural Education, Vol.XXX1V, N.1, 1980.

19.Lyndon, Donlyn, "In Situ, Etc", Journal of Architectural Education, Vol.XXX1V, N.1, 1980.

20.Moholy-Nagy, "How Not To Teach Architectural History", Journal of Architectural Education, Vol.XXX1V, N.1, 1980.

21.Morris, Ellen K, "Teaching History Typologically", Journal of Architectural Education, Vol.XXX1V, N.1, 1980.

22.Newton, Barry, "The Tree of Architecture", Type and the (Im) Possibilities of Convention, CALA, U.S.A., 1991 .

23.Nesbitt, Kate, "Theorizing a New Agenda For Architecture", Princeton Architectural Press, New York, 1996.

24.Schneider, Peter, " Matrix of Memory", Journal of Architectural Education, Vol.XXX1V, N.1, 1980.

25.Snyder \& Catanese, James C \& Anthony J, “ Introduction to Architecture", McGraw-Hill Book Company, USA,1979.

26.Speck, Lawrence, " Mainstream is Almost All Wrong” Journal of Architectural Education, Vol.XXX1V, N.1, 1980. 
27.Tzonis, Alexander \& Liane Lefaivre, "History is Returning to Design", Journal of Architectural Education, Vol.XXX1V, N.1, 1980.

28.University of Maryland, Program in Architecture, Visual analysis, Arch 448R/648R, Summer in Rome 2006. www.arch.umd.edu/Rome2006/ARCH 448R.htm

29.Vickery, Robert L, "Teaching Theory To Beginning Student", Journal of Architectural Education, Vol.XXX111, N.3, Spring 1980.

30.Watkin, David, "The Rise Of Architectural history", The Architectural Press, London, 1980.

Watts, Carol Martin, "Slide Dissolve as Technique”, Journal of Architectural Education, Vol.XXX1V, N.1, 19

تم اجراء البحث في كلية الهنسسة - جامعة الموصل 